\title{
Transitional justice and reconciliation in the Western Balkans: approaches, impacts and challenges
}

Huma Haider

Independent consultant

25 January 2021

\section{Question}

Review the literature on the approaches taken, impact achieved and major challenges faced by transitional justice and reconciliation programmes and policies in the Western Balkans in relation to the wars of the 1990s.

\section{Contents}
1. Summary
2. Background, concepts and approaches
3. Trials
4. Truth-telling
5. Art and culture
6. Memorialisation
7. Dialogue
8. Education
9. References other Government departments, but the views and opinions expressed do not necessarily reflect those of FCDO, the UK Government, K4D or any other contributing organisation. For further information, please contact helpdesk@k4d.info. 


\section{Summary}

Countries in the Western Balkans have engaged in various transitional justice and reconciliation initiatives to address the legacy of the wars of the 1990s and the deep political and societal divisions that persist. There is growing consensus among scholars and practitioners that in order to foster meaningful change, transitional justice must extend beyond trials (the dominant international mechanism in the region) and be more firmly anchored in affected communities with alternative sites, safe spaces, and modes of engagement (Fairey \& Kerr, 2020). This rapid literature review presents a sample of initiatives, spanning a range of sectors and fields - truthtelling, art and culture, memorialisation, dialogue and education - that have achieved a level of success in contributing to processes of reconciliation, most frequently at the community level. It draws primarily from recent studies, published in the past five years. Much of the literature available centres on Bosnia and Herzegovina $(\mathrm{BiH})$, with some examples also drawn from Serbia, Kosovo and North Macedonia.

There tends to be a lack of systematic and robust evaluation of transitional justice and reconciliation initiatives in the region (Fairey \& Kerr, 2020). The evidence base is fragmented, with shortages of studies also noted in specific areas (e.g. arts, heritage, and alternative forms of truth-telling) (Fairey \& Kerr, 2020; Fairey et al., 2020; Hisari \& Fouseki, 2020; Moll, 2020). This report is a step toward pooling together findings from various evaluations and studies available, looking at specific impacts, common approaches and challenges.

\section{Impacts of transitional justice and reconciliation mechanisms and processes}

$\underline{\text { Trials }}$

- Studies on the impacts of international criminal trials conclude that they have either failed to promote reconciliation, or have hindered this process (Strupinskienè, 2020; see Hehir, 2019).

- A focus on legal procedures that prevent victims from telling their stories can undermine their sense of agency (Sivac-Bryant, 2016; cited in Strupinskienè, 2020).

- Political propagandists and local media in the region have used trials and their outcomes to portray their national group as the collective victim (Geis et al., 2019; see Haider, 2016).

- A study of youth attitudes finds that those who believe the International Criminal Tribunal for the former Yugoslavia (ICTY) has had a positive impact in punishing war criminals are 14.7 percent more likely to believe in the possibility of reconciliation (Meernik et al., 2016, 425).

- Research conducted in Prijedor, $\mathrm{BiH}$, finds that the political space created by the conviction and removal of high level political and military leaders can eventually open up opportunities for inter-ethnic collaboration (Zyberi \& Letnar Černič, 2015; Strupinskienè, 2020).

\section{Truth-telling}

- Mutually exclusive public 'truths' about the past is often considered to be a key hindrance to reconciliation Bešić \& Džuverović, 2020; Subotic, 2015; Kurze \& Vukusic, 2013).

- There is a growing view, however, that truth-seeking mechanisms should not seek to establish a unitary 'truth' in divided societies (Di Lellio \& McCurn, 2013; Rowen, 2013).

- Given the absence of official truth commissions, truth-telling has been rooted in civil society. 
- Research on the regional Women's Court finds that it delivered justice to women by giving them the space to tell their personal stories without interruption or constraint (Clark, 2016).

- The Kosovo Memory Book and other documentation that lists information of killed and missing persons of all ethnic groups, while not guaranteeing an official acknowledgment, is considered as a source of recognition and inclusive commemoration (Schwandner-Sievers \& Klinkner, 2019; Baliqi, 2017; Di Lellio \& McCurn, 2013).

- The Bosnian War Crimes Atlas that provides an interactive map of locations of past war crimes, mass graves, and monuments in $\mathrm{BiH}$ provides knowledge, including from trials, in an accessible way that prevents manipulation of the past.

- Research on My Story, which engages in multi-ethnic storytelling by victims, finds a subsequent decline in denial of the out-group's suffering that can also contribute to acknowledgement of crimes committed by the in-group (Oberpfalzerová et al., 2019).

- Studies of an initiative in $\mathrm{BiH}$ that exposed youth to narratives of rescuers who crossed the ethnic divide (moral exemplars) finds that they increased participants' willingness to forgive the out-group's misdeeds and their belief in reconciliation (Čehajić-Clancy \& Bilewicz, 2017).

\section{$\underline{\text { Art and culture }}$}

- Art can make archival and trial documents more accessible, such as Serbian artist Miladinović's ink washed drawings of evidence from ICTY trials (Kerr, 2020).

- The Historical Museum of $\mathrm{BiH}$, through its various exhibits, including on the theme of Reconciliations, has attracted new audiences and encouraged different forms of engagement with BiH's contested past - becoming a key site of deliberation (Fairey \& Kerr, 2020).

- Performance art can become 'strategic confrontation spaces' that push for a reckoning with the past (Kurze, 2016). The Thinking of You installation in Kosovo (with 5,000 donated skirts and dresses hung from washing lines) attempted to confront the stigma surrounding sexual violence. It has contributed to a degree of recognition of wartime rape (Krasniqi et al., 2020).

- Performance art can help to sustain collective memory, such as the wall in Prishtina, with the names of 1,819 ethnic Albanian and Serbian missing persons; and the painting of faded Sarajevo Roses (marks from mortar shells) to make them more visible (Kurze, 2016).

- The Balkan Diskurs Youth Correspondent Programme (BDYCP) seeks to build the capacities of young artists to produce inclusive counter-narratives. Research finds that it strengthened participants' levels of trust in other ethnic groups, attitudes toward inter-ethnic collaboration and reconciliation, and resolve to work towards durable peace (Fairey and Kerr, 2020).

- Most Mira, a Prijedor based theatre company, uses humour to discuss contentious topics and portray unifying aspects of life and identity. Research finds that it fostered a strong sense of solidarity in the group and provided valued space for open dialogue (Milatovic-Ovadia, 2016).

- Dah - a Serbian theatre company, has produced performances that engage with responsibility to the past and accountability (Simić \& Milošević, 2014). Research finds that they have contributed to reconciliation by fostering dialogue and sharing of stories, as a source of recognition to victims, and as commemoration spaces (Simić \& Milošević, 2014).

\section{$\underline{\text { Memorialisation }}$}

- Memorials throughout the region are largely based on a one-sided pattern, recognising only the victims of one group and/or shaming the 'other' (Bădescu, 2019a; Baliqi, 2017). 
- Heritage preservation is also shaped along ethnic lines (Wollentz, 2019).

- Memorials dedicated to children and museums can serve as outliers (Bădescu, 2019a). The Sarajevo under Siege exhibition does not adopt an ethnic framework, but focuses on the commonality of experiences among residents and resilience (Bădescu, 2019a).

- Research on the affective strategies employed at the War Childhood Museum in BiH finds that the focus on personal stories enables visitors to experience war from the child's perspective and to honour victims in an apolitical manner (Niksic, 2020).

- Shared heritage spaces such as Vraca Memorial Park in Sarajevo and the Partisan Memorial Cemetery in Mostar (both dedicated to those who died in World War II), can help to forge a collective identity, yet have been abandoned (Dougherty, 2019).

- Research finds that the creation of a monument to miners from the socialist period in Mostar and participation of diverse community members enabled the prominence of alternative identities and narratives (Wollentz, 2019).

\section{Dialogue}

- A recent study of the Nansen Dialogue Centre (NDC) Sarajevo finds that it has contributed to de-ethnicising everyday problems and forging a common identity based on the discovery of shared concerns and joint activism (Šerá Komlossyová, 2019).

- Another study of NDC Mostar finds that dialogue activities in Capljina did not amplify the already positive effects occurring from everyday increases in contact with the 'other'. It challenged ideas about the in-group though, lowering levels of in-group trust (Cleven, 2020).

- The Youth Peace Camp in Kosovo enables young people to hear personal stories from the conflict. Research finds that the dialogue initiative contributed to positive changes in the perception of the 'other' and the development of empathy, primarily through joint work, conversations about the war, and learning other points of view (Radosavljević, 2018).

\section{Education and extra-curricular activities}

- Research based on a regional survey finds that students from 'mixed' schools were 7.2 percent more likely to believe in the possibility of reconciliation (Meernik et al., 2016, 425).

- Research on the Mostar Gymnasium, an integrated school, finds that it has improved levels of inter-ethnic interaction and enabled re-negotiation of narratives and identity (Forde, 2018; Hromadžić, 2011). Another study on the United World College (UWC - an international school in Mostar) finds that it has helped to shape new identities (Osler \& Pandur, 2019).

- Research on 'shared learning' (language and multicultural workshops, extra-curricular activities) in North Macedonia finds that it has contributed to positive inter-group encounters, but has not allowed for discussion of contentious issues (Loader et al., 2018).

- Studies of inter-ethnic extra-curricular sport in Kosovo and North Macedonia find that they create positive perceptions of the other and openness to inter-ethnic friendships (Krasniqi and Krasniqi, 2019; Giulianotti et al., 2017; Anastasovski et al., 2016).

- 'Multiperspectivity', which allows for interpretation of the past from various perspectives, and the moral exemplar approach, offer alternative methods for teaching history that are less divisive (Čehajić-Clancy \& Bilewicz, 2020; Jeftić, \& Joksimović, 2014). 
- Research suggests that effective integrated schooling also requires civic education. UWC students, who took part in cross-community projects through mandatory service-learning, felt empowered to act and to continue to engage in peacebuilding (Osler \& Pandur, 2019).

\section{Common and emerging approaches across mechanisms}

Storytelling: Sharing of personal stories is a common component of truth-telling, dialogue, art, theatre and museum testimonies. Various studies find that it can rehumanise people, construct more complex views of each other, and contribute to mutual understanding, acknowledgment and empathy - key aspects of reconciliation (Niksic, 2020; Oberpfalzerová et al., 2019; Radosavljević, 2018; Nikolić-Ristanović, 2015). Women who gave testimony at the Women's Court also valued the ability to tell personal stories, uninhibited and uninterrupted (Clark, 2016).

Multiple narratives and 'truths': Unofficial truth-telling mechanisms often allow for the coexistence of different interpretations of the truth, recognising the value in allowing for personal narratives (Rowen, 2013). In history education, where the presentation of a single narrative may also have limited value, multiperspectivity offers an alternative approach (Jeftić, \& Joksimović, 2014).

Challenging stereotypes: Listening to personal stories can challenge stereotypes. Narratives of moral exemplars and learning about members of the 'enemy' group who opposed what was occurring in their name, such as through Dah theatre and the Reconciliations exhibit, can also counter stereotypes and perceptions of collective guilt (Kerr, 2020; Simić \& Milošević, 2014).

Confronting the issue of missing persons: A key motivation for individual involvement in RECOM, the Regional Commission set up for fact-finding and truth-telling, was the hope that it would provide information on missing persons (Di Lellio \& McCurn, 2013). The wall installation in Kosovo with the names of missing persons also had empty chairs in front to signify that families still await recognition of the fate of their loved ones (Kurze, 2016). One of Dah theatre's plays presented testimonies from Bosnian and other women that emphasised the need to know the truth about missing loved ones and to keep their memories alive (Simić \& Milošević, 2014).

Non-violent communication: Adopted in various initiatives, this form of communication seeks not to accuse or offend. In My Story, participants told their personal 'truths' in a way that avoided blaming individuals of a particular ethnicity or bringing up narratives about who is culpable (Oberpfalzerová et al., 2019). The Third-Way form of dialogue, driven by civil society in Serbia, seeks to promote open dialogue and two-way communication, avoiding accusatory discourse that can block discussion and mutual understanding (Nikolić-Ristanović, 2015). Memorials that adopt rigid storytelling are also considered to prolong conflict through symbolic humiliation, whereas the memorial dedicated to the children who died in Sarajevo commemorates them without antagonising a particular group (Bădescu, 2019a). The testimonies at the War Childhood Museum are devoid of identifying the perpetrator or assigning blame or responsibility, thus adopting an apolitical stance to the war (Niksic, 2020). Such an approach may not satisfy everyone, however, as some victims may prefer for the perpetrator to be named.

Multiple identities and instrumental activities: Initiatives often seek to draw attention to identities other than ethnicity. A theatre activity in Prijedor sought to unite participants by focusing on social roles outside of nationality and on common issues (Milatovic-Ovadia, 2016). Further, working on the joint activity of creating a play, similar to other instrumental activities, enabled youth to develop a sense of solidarity (Milatovic-Ovadia, 2016). This has also been the case with other 
cultural activities, such as music, art and heritage, and sporting activities (Krasniqi and Krasniqi, 2019; Howell, 2018; Wollentz, 2018). By enjoying such activities together, participants can learn to see each other individually (Hrstić, 2020). NDC Sarajevo also fostered attention to shared interests and concerns and to identities aside from ethnicity in order to foster cooperation, build trust, and change perceptions of the 'other' (Šerá Komlossyová, 2019; Kelleher and Ryan, 2012).

Attention to Youth: Reconciliation outcomes in the Western Balkans will rest in large part on the efforts of youth (Meernik et al., 2016). Many of the reconciliation activities throughout the region are directed toward youth. Various studies note that youth do not have many opportunities to learn about the war or discuss the past with their parents, educators, or society in general, due to a common refusal to discuss the wars (Kurze, 2016; Milatovic-Ovadia, 2016). Research on UWC finds that students appreciated classroom environments where teachers foster open dialogue (Osler \& Pandur, 2019). Youth have also sought out their own information and knowledge through alternative, transnational sources (Kurze, 2016).

Children as an entry point: Remembrance of children can be an effective unifying approach, such as the memorial dedicated to children in Sarajevo (Bădescu, 2019a). The White Armband Day campaign in Prijedor that seeks to memorialise ethnic cleansing in the town, made progress in establishing a yearly commemorative event in large part through the activism of youth and diaspora, but also by focusing on the memory of children (Karabegović, 2019).

Iterative approaches: Initiatives have in some cases begun on a small scale, with piecemeal activities, gradually evolving through an iterative process into something bigger and/or different. This has been the case with the Historical Museum in $\mathrm{BiH}$, which has through an accumulation of exhibits come to be considered an important site of national dialogue (Fairey \& Kerr, 2020). Similarly, the BDYCP developed over various cycles of workshops, evolving from two prior initiatives involving 'Ordinary Heroes' (moral exemplars) (Fairey \& Kerr, 2020).

\section{Challenges in designing and implementing mechanisms}

Wider impact: A key challenge is achieving wider impact beyond the immediate participants. Studies measuring these wider impacts are limited (Garson, 2020). They could be assessed in part by whether participants go on to develop their own initiatives and the formation of 'peace constituencies' (Garson, 2020). Youth who attended the Pavarotti Music Centre went on to establish other venues that also challenge narratives and divisions (Howell, 2015). The 'Nansen kids', who took part in dialogue workshops, engaged in successful activism in Jajce, BiH, to stop plans for segregated schools (Šerá Komlossyová, 2019). Art projects (e.g. Pillar of shame) and museum activities (e.g. Reconciliations) have at times partnered with educational institutions to reach educators and students (Fairey \& Kerr, 2020; Simić, 2013). The BDYCP and the Youth Peace Camp have also sought to provide participants with the skills and tools to influence wider communities and form larger peace constituencies (Fairey and Kerr, 2020; Radosavljević, 2018).

Political obstruction and sustainability: While there is evidence of micro-level projects 'rippling outwards' and 'trickling upwards', it remains very difficult to impact the elite, political level (Garson, 2020). In turn, if participants' environments continue to be based on segregationist and nationalistic ideas, the impact and sustainability of reconciliation activities can be undermined (Hrstić, 2020; Radosavljević, 2018). Political obstruction has been evident throughout the region. The historical record produced by trials has been used by political propagandists to further the 
view of one-sided victimisation (see Haider, 2016). Political actors have also produced a divisive memorial landscape, blocked the development of official national truth commissions, and undermined support for the region-wide truth commission, RECOM (Bãdescu, 2019a and 2019b; Clark 2016; Dragović-Soso, 2016). Public authorities have given little support to grassroots projects (e.g. moral exemplar initiatives) or have directly opposed them (e.g. Dah theatre productions) (Moll, 2020; Simić \& Milošević, 2014). The Thinking of you project was unique in receiving political support from the president of Kosovo (Krasniqi et al., 2020).

Civil society cooperation and sabotage: Cooperation among civil society can also be challenging, reflecting regional divides. One of the leading Bosnian NGOs pulled out of RECOM as it found that Croatian and Serbian NGOs were leading the process (Touquet \& Vermeersch, 2016). The Pillar of Shame installation was undermined by lack of willingness of NGOs from the two different entities in $\mathrm{BiH}$ to collaborate (Simić, 2013). There is also the risk of sabotage, such as audience members verbally attacking shared personal stories (Oberpfalzerová et al., 2019). In Kosovo, the installation with the names of missing persons was vandalised by members of the Kosovar victim community, who crossed out Serbian names (Kurze, 2016; Di Lellio \& McCurn, 2013).

Balancing reconciliation processes: Initiatives often have to strike a sensitive balance in facing the past without endangering social cohesion (Rehrmann et al., 2020). In North Macedonia, 'shared learning' has focused on exploring diverse cultural backgrounds and increasing student interactions, avoiding discussion of contentious issues, in order not to risk undermining the delicate harmony (Loader et al., 2018). Truth-telling initiatives are subject to varying approaches: seeking to unite contradictory versions of the truth to avoid manipulation of facts, while also allowing for the co-existence of multiple truths (Di Lellio \& McCurn, 2013; Rowen, 2013). In BiH, victims associations were opposed to a TRC in large part because they opposed any kind of truth that would create symmetry between their suffering and that of others (Dragović-Soso, 2016).

Balancing attention to identities: Initiatives also have to strike a balance between recognition of the salience of ethnicity and focus on alternative identities. Dialogue encounters in the region often bring participants together based on ethno-religious identities. This could lessen the importance of other possible identities and create a starting point where narratives are explored solely through the lens of ethnicity (David, 2018). Local government mechanisms have been considered ineffective in bridging divides by viewing dialogue as a means of solving inter-ethnic conflict and promoting cultural differences rather than a forum to discover issues that affect people as members of a wider local community (Djordjević, 2018). NDCs have also brought together participants based on ethnicity, but have then sought to foster discussion that reveals shared concerns and local activism, which can lessen the salience given to ethnicity (Šerá Komlossyová, 2019). This is the approach adopted in instrumental reconciliation that seeks to bring people together to focus on art, sport, or development among other activities.

Victimhood and gender-based violence: The way in which women and war-time violence is portrayed has been the subject of much debate in the literature. The Women's Court experienced controversy with Bosnian NGOs wanting the focus to be on sexual violence, while others wished to expand the narratives of women beyond sexual violence (Clark, 2016). Initiatives, such as trials and civil society projects that focus on the victimhood of women are also considered by some as undermining stories of resilience and women's agency (Clark, 2016). At the same time, there have been significant struggles for recognition of war-time sexual violence - e.g. with the Thinking of You installation in Kosovo; and the critique that the Srebrenica-Potočari memorial's 
lack of memorialisation of mass rape has contributed to the suppression of rape memory (Jacobs, 2017). The key issue may be the role of external actors defining what women should remember and focus upon from the war, rather than letting them decide. A suggested approach could be to allow for multiple discourses housed in one memorial site; and truth-telling that gives women the space to narrate what is of importance to them (Clark, 2016; Jacobs, 2016).

\section{Background, concepts and approaches}

The wars in the former Yugoslavia in the 1990s began in Slovenia, spreading to Croatia, Bosnia and Herzegovina $(\mathrm{BiH})$ and, subsequently to Kosovo (Simić, 2016). The entire region was affected by armed conflict directly or indirectly and is still recovering from the consequences (Mastrorocco, 2020; Simić, 2016). The region suffers from deep political and societal divisions, with differing narratives embedded in mainstream public discourse and continuing ethnic segregation (Zyberi \& Letnar Černič, 2015). These divisions influence the view of transitional justice processes and outcomes. Transitional justice refers to 'the full range of processes and mechanisms associated with a society's attempts to come to terms with a legacy of large-scale past abuses, in order to ensure accountability, serve justice and achieve reconciliation'1.

Countries in the Western Balkans have engaged in multiple transitional justice mechanisms, some indigenously, and some in response to international initiatives (Mastrorocco, 2020; Subotic, 2015). The most prominent transitional justice mechanism supported by international actors has been the creation of international, national and local levels of war crime trials, most notably the ICTY (see 'Trials' section). Despite implementation of trials and other transitional justice mechanisms, the legacy of the wars continue to challenge political, economic, and social development and to obstruct inter-state and inter-ethnic cooperation (Fairey et al., 2020; Mastrorocco, 2020). Reconciliation is a key development challenge in the region. Failure to address loss of trust, destroyed relationships, polarisation and trauma increases the risk of new spirals of violence (Fischer, 2013).

\section{Reconciliation: concepts and approaches}

Reconciliation has been articulated as a goal of many transitional justice processes and mechanisms. There is limited consensus, however, on what reconciliation entails and how it should be promoted. It has been defined as 'a process through which a society moves from a divided past to a shared future' (Bloomfield, 2003, 12; cited in Haider, 2016). From a peacebuilding perspective, it may be seen as the process of repairing relationships at all levels of society and confronting dominant narratives of the past (see Haider, 2016). Reconciliation can occur at the individual, inter-group or communal, societal, or political levels and be described as 'thin' or 'thick'. 'Thinner' definitions may involve individuals living alongside one another without violence (Strupinskienè, 2017; Meernik et al., 2016). 'Thicker' definitions entail active work on the part of all concerned to forge new relationships, to restore dignity to those who have suffered, and to acknowledge and accept truths of the past (Strupinskienè, 2017; Meernik et al., 2016).

\section{Socioemotional and instrumental processes of reconciliation}

\footnotetext{
1 UN Security Council (2004). The rule of law and transitional justice in conflict and post-conflict societies. S/2004/616. 23 August.
} 
Most authors agree that reconciliation describes a process, in many cases a complex, non-linear process, rather than an end state or outcome (Strupinskienè, 2019). Reconciliation efforts within the field of transitional justice may need to strike a sensitive balance in facing the past without endangering social cohesion (Rehrmann et al., 2020). Various initiatives attempt to achieve both fostering inter-group contact and addressing the past.

- Contact and relationship-building: 'Instrumental' processes toward reconciliation (or 'instrumental reconciliation') involve the development of positive inter-group interactions with a focus on the present or the future - often through shared activities and cooperation toward common goals (Čehajić-Clancy \& Bilewicz, 2020; Garson, 2020). This can allow parties to discover similarities with an individual rather than rely on stereotypes (Garson, 2020). Activities can include drama, music and art; camps and sporting activities for youth; and economic activities and local development projects (Garson, 2020; Radosavljević, 2018).

- Facing the past: 'Socioemotional' processes that address the past aim to find ways of dealing with the emotional consequences created by the history and memory of conflict (ČehajićClancy \& Bilewicz, 2020). Such processes often aim to challenge beliefs formed during the conflict, such as the dehumanisation of the rival group and glorification of one's own group (see Milatovic-Ovadia, 2016). This requires spaces in which story-telling can be shared, contrasting narratives acknowledged, suffering and wrongdoing on both sides recognised and empathy fostered (Karić \& Mihić, 2020; Rehrmann et al., 2020; Milatovic-Ovadia, 2016). This can create the basis for an inclusive collective memory (see Rehrmann et al., 2020).

\section{Local meanings of reconciliation}

There can be local divergences in the interpretation of 'reconciliation'. A study of reconciliation in the Prijedor municipality in $\mathrm{BiH}$, the area where the Omarska, Trnopolje and Keraterm concentration camps were based, finds that a large number of people claimed that reconciliation exists in their town. They primarily defined reconciliation, however, in 'thin' terms - as the absence of conflict and re-establishment of contacts among groups. A smaller number of the people interviewed claimed that Prijedor was not reconciled, viewing reconciliation as also including trust, forgiveness, and genuine engagement with the past (Strupinskienè, 2017).

Another study on how Bosniaks and Serbs in BiH define reconciliation finds that 'facing the past' as a component of reconciliation is almost exclusively mentioned by Bosniaks (Karić \& Mihić, 2020). Respondents of both ethnicities, however, interpreted reconciliation as involving 'ordinary life' - referring to interacting with members of the outgroup and engaging in everyday activities, such as work or education (Karić \& Mihić, 2020). Respondents emphasised that if there were enough jobs, people would connect through economic opportunities, prompting greater progress toward reconciliation (Karić \& Mihić, 2020). Similarly, a study of youth views toward reconciliation finds that students from communities with higher unemployment rates are less likely to believe in the possibility of reconciliation, due to preoccupation with addressing immediate needs and fewer opportunities for social interaction (Meernik et al., 2016).

Throughout the Western Balkans, the term 'reconciliation' is often strongly resisted, seen as antijustice, artificial and controlled, or as a politics of distraction from more pressing needs (Kerr, 2020; Sokolić, 2020). To some, it reflects the impossibility of dealing satisfactorily with the past (Kerr, 2020). In recent years, practitioners have used the term less, opting instead for the formulation of 'moving forward', which has fewer negative connotations (Fairey et al., 2020). 


\section{Broadening transitional justice}

The debate about whether transitional justice contributes to reconciliation is ongoing and in need of more empirical support (Haider, 2016). The focus on criminal trials and top-down approaches has been critiqued for making assumptions about victims and their needs (Fairey \& Kerr, 2020; Garson, 2020). Not only can this be disempowering, it can also produce a problematic disconnect between the aspirations of transitional justice and on-the-ground realities (Garson, 2020).

There is growing widespread consensus among scholars and practitioners that in order to foster meaningful change, transitional justice should be more firmly anchored in the communities most affected, and linked to a future-oriented transformative agenda (Fairey \& Kerr, 2020; Garson, 2020). This requires broader societal mechanisms and a range of bottom-up initiatives that give a greater voice and role to survivors (Karabegović, 2018; Clark, 2016; Simić, 2016). There is thus a need for alternative sites, safe spaces, and modes of engagement through which people can deliberate and frame the past, in relation to the future, in their own terms (Fairey \& Kerr, 2020).

\section{Scaling up the level of impact: from the micro to the macro}

The impact of peacebuilding processes is frequently measured downwards, looking at the effects of political-level changes at the micro level (Garson, 2020). The process of reconciliation may already be occurring in societies, however, in varying formats and contexts (Sokolić, 2020). At the same time, isolated group shifts need to ripple outwards and trickle upwards (Garson, 2020).

While there are indications that inter-group activities in $\mathrm{BiH}$ have led to the development of friendships and the creation of a network of people committed to peacebuilding ('peace constituencies'), there is frustration that this has had little impact at the elite level (Garson, 2020).

There can be differing local perceptions of whether bottom-up or top-down reconciliation processes are occurring. A survey of residents of Prijedor finds, for example, that there is both a narrative of spontaneous (bottom-up) reconciliation and forced (top-down) reconciliation. The former narrates how returnees enabled the resumption of necessary everyday interactions that over time contributed to trust building and eventually political cooperation (Strupinskiené, 2017). The top-down narrative begins with ICTY indictments and arrests that enabled more moderate politicians gain power and provide the space for reconciliatory processes (Strupinskiené, 2017).

\section{Evaluation and evidence}

There is much research that highlights the insufficient evidence base and lack of systematic and robust evaluation of transitional justice initiatives (Fairey \& Kerr, 2020). Research has often focused on analysis of judicial aspects, with limited examination of reconciliation processes (Ferati-Sachsenmaier, 2019). Key limitations of and challenges include:

- Varying definitions: There is inconsistency about what reconciliation comprises, including in terms of measures and indicators (Fairey et al., 2020). The intangibility of many of the elements crucial to reconciliation can also make it difficult to quantify (Fairey et al., 2020).

- Short-termism: The funding that is available for reconciliation activities is often structured around short-term project cycles, which can undermine risk taking and iterative processes (Fairey et al., 2020). It also limits the capacity of local organisations to build up knowledge and trust with local communities, and to invest in and retain skilled staff (Fairey et al., 2020). 
- Vertical accountability: Accountability mechanisms in the peacebuilding field are almost exclusively based on organisations reporting upwards to donors and governments (Fairey et al, 2020). There is little emphasis on accountability to the project beneficiaries or consultation with beneficiaries on project design and evaluation methods (Fairey et al, 2020).

- Shortage of evidence of wider impacts: Studies measuring wider impacts and changes in the overall environment are limited, focusing instead on the direct effects of individual programmes on participants (Garson, 2020). Assessments of wider impacts could include measurements of whether participants go on to develop their own initiatives; subsequent ability to resist provocation to violence; and reduction of threat of violence (Garson, 2020).

- Failure to share knowledge: While there is a growing knowledge base amongst communities and practitioners on reconciliation activities, this has not translated into applied shared evaluation learning and frameworks (Fairey et al., 2020). The evidence base is fragmented, with an absence of evaluation synthesis and meta evaluations (Fairey et al., 2020).

\section{Trials}

The UN Security Council established the ICTY in 1993 at the Hague to bring to trial those responsible for violations of international humanitarian law in the former Yugoslavia during the 1990s (Simić, 2016). It initially stood out as the key instrument that would bring justice and allow for the rebuilding of relations among the divided parties (Mastrorocco, 2020). In theory, the individualisation of guilt through criminal trials should reduce the perceived need to hold entire ethnic communities responsible for violations; and the sentences meted out to the guilty are intended to provide justice for the victims and affected communities (Meernik et al., 2016).

Criminal trials have created opportunities for some survivors to achieve public recognition of their suffering, confront perpetrators, and see perpetrators held accountable (see O'Reilly, 2016). Significant steps were taken to secure witness testimony from survivors of sexual violence, through support and protection measures that have enabled their representation (O'Reilly, 2016).

In addition to the ICTY, international pressures on the region included the establishment of domestic war crimes trials (Subotic, 2015). Serbia established its War Crimes Chamber (WCC) in 2003 to try cases in its national courts (Simić, 2016). In BiH, the WCC began in 2005, housed within the State Court. The majority of cases transferred by the ICTY have been brought before the Bosnian WCC (Zyberi \& Letnar Černič, 2015). In Croatia and Kosovo, governments also pledged to prosecute war crimes in front of domestic courts, while North Macedonia received referral cases from the ICTY to prosecute cases in domestic courts (Subotic, 2015). In 2015, the Kosovo Specialist Chambers was established by the Kosovo Assembly, tasked with investigating crimes allegedly committed by the Kosovo Liberation Army (Hehir, 2019).

\section{Politicisation of trials and inadequate attention to victims' needs}

Despite high expectations for the impacts of criminal trials, the ICTY's record of achieving justice and reconciliation in the former Yugoslavia has been criticised, with many studies concluding that it either failed to promote reconciliation, or hindered this process (Strupinskiené, 2020; see Hehir, 2019). A key issue cited in the literature is that the ICTY lacked local legitimacy, due in large part to its physical distance from the former Yugoslavia and the lack of engagement with people on 
the ground (Hehir, 2019). Local populations perceived the work of the ICTY as distant and abstract, even if their overall impression may have been positive (Zyberi \& Letnar Černič, 2015).

Various scholars have also critiqued the ICTY (and criminal trials generally) for inadequately addressing the needs of victims, through a focus on the perpetrators and legal procedures that prevented victims from telling their stories, undermining their sense of agency (Sivac-Bryant, 2016; cited in Strupinskiene, 2020). Lack of outreach (early on), poor witness protection and insufficient reparations are other factors that hindered the tribunal from truly addressing the needs of victims (see Strupinskienè, 2020). Criticism has also been raised with respect to the ICTY's ability to punish the perpetrators, in terms of slow and time-consuming processes, lenient sentences, and many perpetrators remaining unpunished (Strupinskienè, 2020; O'Reilly, 2016).

The historical record produced by trials has also been used by political propagandists to further the view that their national group is the victim of the conflict, causing further suspicion and fear among divided communities (see Haider, 2016). In Serbia, the political scene became split between nationalist, anti-Hague forces on the one hand, and pro-Hague groups and individuals on the other, which had a significant negative influence on reconciliation (Nikolić-Ristanović, 2015). Nationalist politicians throughout the region have in some cases gained greater support after being sanctioned by the ICTY (Hehir, 2019). Conflicting reactions to verdicts, such as to the conviction of Radovan Karadžic, also demonstrate how divided the region remains - and how elusive a shared narrative can be (Milatovic-Ovadia, 2016). Such divided reactions were also particularly evident in the acquittal of Naser Orić, a former Bosnian military official, first at the ICTY and subsequently in the State Court of BiH (Haider, 2011).

\section{Divisive media campaigns}

The media can play an important role in how prosecutions are perceived. Research on mainstream news reporting of the ICTY trials in Serbia, for example, finds that all three TV stations analysed (PINK, RTS and B92) reproduced the view of Serbian collective victimhood while seeking to 'normalise' Serb defendants, through symbolic images of the state (Geis et al., 2019). Stories also centred on the perspective of the Serb defendant (a concern with their fate, their family, the possibility of early release or appeal) (Geis et al., 2019). In contrast, the visual presentation of non-Serb defendants emphasised images displaying victims, war destruction or attacks, which are absent in the portrayal of Serb defendants (Geis et al., 2019). Reporting on the local Serbian WCC is also problematic and partial (Subotic, 2015). A study of leading daily print newspapers in Kosovo and Serbia also finds that interpretations of the Kosovo conflict and its outcome, and notions of justice, were predominantly portrayed through ethno-nationalist lenses, with an absence of stories about inter-ethnic reconciliation (Ferati-Sachsenmaier, 2019). While there has been much criticism of the ICTY's failure to implement an effective outreach programme early on, it is uncertain whether outreach can adequately counter biased local media structures (Geis at al., 2019).

Other research demonstrates that if information about the tribunal's 'positive contributions' in providing justice could be effectively disseminated, support for international justice and domestic reconciliation may improve (Meernik et al., 2016). A study of the determinants of reconciliation among students finds that those who believe the ICTY has had a positive impact in punishing war criminals are 14.7 percent more likely to believe in the possibility of reconciliation (Meernik et al., 2016, 425). The study also finds that individuals who accept to some extent the ICTY's 
judicial record, showing that members of all ethnic groups have committed violations of international law, are 9.4 percent more likely to believe in the prospects for reconciliation (Meernik et al., 2016, 426). They are more likely to question the narratives that claim their ethnic groups were always the victim and never the perpetrator (Meernik et al., 2016).

\section{Creating the political space for grassroots mobilisation}

The political space created by the conviction and removal of high level political and military leaders can facilitate the emergence of more moderate leaders (Zyberi \& Letnar Černič, 2015). A field study on the wider impacts of the ICTY finds, through interviews and observations, that there is a link between ICTY activities and inter-group reconciliation (Strupinskiené, 2020). The process begins with the indictment and physical removal of elite, who would otherwise have been spoilers of reconciliation, and the entrenchment of the norm of accountability for crimes committed (Strupinskienè, 2020). In Prijedor, this produced an environment in which Bosniaks felt safe to return. They voted in more moderate politicians, which opened up opportunities for inter-ethnic contact and collaboration (Strupinskiené, 2019). The norm of accountability also empowered victims to organise themselves to demand justice, across ethnic lines, opening up spaces for processes of reconciliation (Strupinskienè, 2020).

\section{Truth-telling}

Seeking truth about the past is an overarching goal of transitional justice (Simić, 2016). Among the most well-known truth-seeking mechanisms is truth and reconciliation commissions (TRCs): official, non-judicial bodies of limited duration established to determine the facts, causes and consequences of past human rights violations (see Haider, 2016). They aim to resolve and unite contradictory versions of the truth in an official account of the past in order to prevent a renewal of conflict through manipulation of history. They also give voice to victims to speak publicly about their suffering and to receive acknowledgement (see Obertpfalzerová et al., 2019).

Public 'truths' about the past in the Western Balkans are mutually exclusive and contradictory, influenced by nationalist discourses of political actors, with each side trying to impose its own version of the past as the legitimate one (Bešić \& Džuverović, 2020; Subotic, 2015; Kurze \& Vukusic, 2013). While this is considered to be a key hindrance to reconciliation, there is limited research on the impact of such contradictory narratives (Bešić \& Džuverović, 2020).

At the same time, there is a growing recognition of the importance of personal truths and individual narratives and the view that truth-seeking mechanisms should not necessarily seek to establish a unitary 'truth' (Rowen, 2013). What 'victims' and other members of civil society often share is the need for their unique experience and their own narratives to be taken seriously, even if the articulation of contrasting 'truths' may be controversial (Di Lellio \& McCurn, 2013). For further discussion, see the section below on 'Unofficial truth-telling'.

\section{Regional initiatives}

RECOM is a regional cross-border initiative strongly rooted in a vast network of NGOs and individual activists (Touquet \& Vermeersch, 2016). An instrument of truth-telling, it seeks to 
investigate and disclose facts about war crimes and other serious human rights violations in the former Yugoslavia (Kurze \& Vukusic, 2013). It aims to raise victims' voices and reflects the view that any attempt at reconciliation should go beyond current state borders (David, 2019; Touquet \& Vermeersch, 2016). A key motivation for individual involvement in RECOM is the hope that it will provide information on missing persons (Di Lellio \& McCurn, 2013).

Since its official start in 2006, RECOM has organised over a hundred meetings across the region and fostered citizens' deliberations on the issues of transitional justice and reconciliation. The establishment of a region-wide truth commission requires the full support of all the region's governments, however, this has proven hard to obtain (Touquet \& Vermeersch, 2016). Local NGO support has also been at issue. In 2008, one of the leading organisations, the Sarajevobased Research and Documentation Centre (RDC), withdrew from RECOM as it found that organisations from Croatia and Serbia were leading the process. Other Bosnian NGOs also complained that their voices were not being heard (Touquet \& Vermeersch, 2016). Relaunched in 2017, Western Balkan leaders are expected to sign a draft collaboration agreement, which would formalize RECOM (Schwandner-Sievers \& Klinkner, 2019).

The Women's Court for the former Yugoslavia is a locally engaged approach to achieving justice and redress for women impacted by armed conflict (O'Reilly, 2016). Approximately 200 NGOs were involved in organising the Court over five years. This included multiple consultations and trainings, seminars, presentations and discussion circles. The final event, the actual Women's Court, was held at the Bosnian Cultural Centre in Sarajevo in May 2015 (Clark, 2016).

One of the aims of the Court was to underscore the continuity of violence against women in times of war and peace. The witnesses played a key role in selecting the themes: war against civilians; women's body as a battlefield; persecution of differences; social and economic violence; and women's resistance (Clark, 2016). This provided women with a significant 'enabling space' to tell their differing experiences and stories (Clark, 2016). Many NGOs in BiH wanted the main focus to be on sexual violence, however, and boycotted the Court. The Serbian NGO Women in Black opposed this, wishing to expand narratives of women beyond sexual violence (Clark, 2016).

During the four-day event, 36 women from across the Western Balkans publicly testified to an audience of approximately 500 people (O'Reilly, 2016). The audience responded with tears, applause, cheers and 'expressive bodily gestures' that conveyed recognition, support and empathy (Clark, 2016). Photos of wartime destruction, anti-war demonstrations and commemoration ceremonies were also exhibited (O'Reilly, 2016).

Impact: While it may be too soon to determine potential longer-term, wider impacts, research explores whether the Court delivered justice to the women who told their stories (Clark, 2016). Adopting a 'justice as recognition' approach, where victims are given recognition of their painful experiences, Clark (2016) concludes that the court successfully delivered justice by:

- Allowing the women to tell their stories in their own words, without any interruptions, and to focus on what was personally most important to them (Clark, 2016). This provided a counter to the restrictive confines of the criminal trial process, whereby victims-witnesses are limited to recounting the specific crimes committed against them (Clark, 2016).

- Enabling the women to speak not only about what they had experienced but also about the emotional and cognitive effect (Clark, 2016). 
- Recognising that crimes of rape are not a one-time event, but have ongoing impacts, such as health problems, marriage breakdowns, and economic adversity (O'Reilly, 2016).

- Giving women the agency to provide a varied account of the harms and losses they endured in wartime beyond sexual violence, such a loss of loved ones (Clark, 2016)

- Focusing not only on women as victims but also on their resilience and agency - their active efforts to recover and rebuild their lives (Clark, 2016; O'Reilly, 2016). This is in contrast to the criminal trial process, where the focus is on victimisation (Clark, 2016).

Challenges: Limitations of the Court include a missed opportunity to explore the lived realities of women (ex)-combatants who can be viewed as both perpetrators and victims; and the absence of a reparations programme, as it was a civil society initiative (O'Reilly, 2016).

\section{Local truth commissions}

There has been only one attempt to establish a TRC in Serbia, in 2001, which was abolished six months after its inauguration due to political turmoil within the TRC Committee (Simić, 2016).

Similarly, in $\mathrm{BiH}$, the idea of a national truth commission, which emerged in the 1990s, encountered resistance on the political and societal level ${ }^{2}$ (Dragović-Soso, 2016). International actors sought to solve this problem by engaging local actors in support of the TRC project (Dragović-Soso, 2016). There was inadequate local momentum, however (Dragović-Soso, 2016). The revival of the TRC project in 2005 by international actors - this time within the Bosnian parliament, involved a new focus on political parties, rather than on civil society, in recognition of the need to achieve political backing (Dragović-Soso, 2016). This time, the project faced stumbling blocks from civil society - from Bosnian victims associations that felt they had not been adequately included in the process (Dragović-Soso, 2016). Moreover, victims associations were opposed to the development of any kind of 'compromise truth' that would create symmetry between their suffering and the suffering of others (Dragović-Soso, 2016).

\section{Unofficial truth-telling}

Truth-telling is not limited to official, state-based truth commissions, but can be unofficial and rooted in civil society (Simić, 2016). Although unofficial initiatives may not be able to establish a society-wide dialogue about the past and to construct a national narrative, the benefits of community-level truth-telling include the ability to be more creative, context-driven and to connect more with communities (Bickford, 2007; cited in Haider, 2016).

\section{Investigative and factual documentation}

The Kosovo Memory Book, produced by Humanitarian Law Centres in Kosovo and Serbia and validated by RECOM, lists killed, missing, and disappeared persons of all ethnic groups from 1998-2000 (Schwandner-Sievers \& Klinkner, 2019; Di Lellio \& McCurn, 2013). The six-volume 'monument', edited in Albanian, Serbian, and English, offers an extensive database, including names of victims, location, and circumstances of their death or disappearance (Baliqi, 2017; Di Lellio \& McCurn, 2013). While the memory book does not guarantee the acknowledgement that

\footnotetext{
2 Bosnian Serb politicians saw any all-Bosnian initiative as a threat to the survival and autonomy of Republika Srpska (RS). Public opinion in the RS also indicated little enthusiasm for a national truth commission,
} 
an official truth commission can provide, it is a key step toward a factual account of violence and human rights violations. (Di Lellio \& McCurn, 2013). The investigative techniques focused on accuracy rather than empathy with victims (Di Lellio \& McCurn, 2013). Nonetheless, it can help to address their need to remember, with some viewing the book as a source of recognition and commemoration that transcends ethnic lines (Baliqi, 2017; Di Lellio \& McCurn, 2013).

Similarly, the Human Losses Project, initiated by the RDC has produced a comprehensive database on human rights violations and a book with the findings (Bosnian Book of the Dead). The project sought to create a collective memory of the victims in $\mathrm{BiH}$ and promote a human rights dialogue in the country (Rowen, 2013). It has experienced political controversy ${ }^{3}$, however, which undermined support for its work (Kurze, 2017). Importantly, however, most politicians in the country now cite the numbers reported by the RDC, which has countered the possibility of manipulation with numbers for political purposes. ${ }^{4}$

The RDC also produced the Bosnian War Crimes Atlas, ${ }^{5}$ a website that uses Google Earth as a platform to host an interactive map of locations of past war crimes and mass graves in $\mathrm{BiH}$ and monuments constructed. There is the capability to view the settings and to learn about specific sites, events and individuals. This required extensive digitisation of documents, including from war crimes trials, examination of archives and databases, and field research. The main aim of the Atlas is to empower Bosnian citizens with accessible knowledge of the war to prevent manipulation of key historical facts; to democratise the process of dealing with the past; and to commemorate all victims regardless of their ethno-religious background (a digital memorial). Presentations to publicise the Atlas and its aims have been given recently throughout the region (BiH, Croatia, Serbia, Kosovo and Montenegro). ${ }^{6}$ There has been a high level of interest in the Atlas, with over 10,000 visitors to the site in one week. ${ }^{7}$

\section{Coexistence of multiple truths - My Story}

A key challenge in the Western Balkans is how to encourage reconciliation if the process presumes one shared truth, while in reality there are a significant number of different and opposing interpretations of truths. In addition, there is often an unwillingness to accept any truth that contradicts their own (Bešić \& Džuverović, 2020). Unofficial truth-telling initiatives have allowed for the co-existence of different interpretations of truths, whereby each side has their own interpretation of truth, but remains open to acknowledge and accept alternative truths that come from the other side (Bešić \& Džuverović, 2020).

In $\mathrm{BiH}$, the Centre for Nonviolent Action in Sarajevo has brought together war veterans from all sides to share their stories and call for peace. The aim is to encourage people to reflect on their role and personal responsibility in relation to the war (Fischer, 2006; cited in Oberpfalzerová et

\footnotetext{
3 Through its investigation and documentation, the RDC reported the number of Bosnian victims to be around 100,000 instead of the 250,000 referred to in Bosnian society, which fuelled uproar among the Bosniak elite. Three independent international experts, including one from the ICTY, validated the findings (Kurze, 2017).

4 Truth seeking, truth telling and truth keeping in Bosnia and Herzegovina: interview with Mirsad Tokača. 25 October, 2011. https://www.everycasualty.org/newsandviews/truth-seeking-bosnia

${ }^{5}$ Available at: http://www.mnemos.ba/ba/home/index

6 forumZFD. (2019). Bosnian War Crimes Atlas presentations in Serbia and Croatia. 20 May. https://www.forumzfd.de/en/bosnian-war-crimes-atlas-presentations-serbia-and-croatia-0

7 "Bosnian War Crime Atlas, 1992-1995". 24 December, 2019. https://www.mreza-mira.net/vijesti/razno/bosnianwar-crime-atlas-1992-1995-2019/\#
} 
al, 2019). Similarly, the NGO initiative, My Story, ${ }^{8}$ adopts multi-ethnic storytelling by victims of the 1992-1995 war to promote reconciliation (Oberpfalzerová et al., 2019). It also adopts 'nonviolent communication' that seeks not to accuse or offend: many of the participants do not name the perpetrators' ethnicity, although the information can sometimes be inferred. The story-tellers frame their stories exclusively as personal accounts, commenting only of what they themselves witnessed (hence My Story) (Oberpfalzerová et al., 2019).

Approximately 230 war victims (former concentration camp prisoners, civilian victims, family members of missing persons etc.) and war veterans were trained in nonviolent communication, and ninety of them were also trained for public testimonies. The testimonies always involve one member of each of the three main Bosnian ethnic groups (Bosniak, Croat and Serb) sitting next to each other with an audience and telling their personal stories of war. Approximately 218 such events had taken place by the end of May 2019 (see Oberpfalzerová et al., 2019).

Impact and findings: Previous research on My Story has shown that public testimonies promote inter-ethnic trust, collaboration, acknowledgement of outgroup suffering, communication and peacebuilding (Hart and Colo 2014; cited in Oberfpfalzerová et al., 2019). A more recent field study, based on observations and interviews with young Bosniaks, Croats and Serbs who took part in My Story, also concludes that this storytelling initiative is beneficial to processes of reconciliation. This is achieved through the content of the stories, the emotions the storyteller conveys, and the messages produced from the stories (Oberpfalzerová et al, 2019).

Content: My Story introduces participants to stories of the other side's suffering, which can challenge conflict narratives and reductionist group identities. They do not erase memory but widen it to include the other's memory (Oberpfalzerová et al, 2019). The stories can also broaden perceptions of the 'other' by hearing about individuals who crossed the divide to help people from the other ethnic group (see Moral exemplars below). One participant - a male Bosnian-Croat told a story of being severely wounded on the frontline and saved by 'enemy' Bosniaks (Oberpfalzerová et al., 2019). Another participant - a male Bosniak - was captured by the Serbian army trying to flee Bosnia and taken to a concentration camp inside of Serbia where he endured torture. He narrated how a Serbian doctor saved his life, and one of his prison guards gave him a blanket and promised nobody would beat him again (Oberpfalzerová et al., 2019).

Emotions and contact: The close contact between participants on an equal status and the interaction between the bodies of the storytellers and the listeners, engaging in a shared activity, can allow for perception of common interests and reduction in prejudice (Oberpfalzerová et al., 2019). Storytellers also give the listeners clues with their body language as to how difficult it is for them to speak about these matters, which would likely not have been picked up so easily if the testimony were broadcast on television (Oberpfalzerová et al, 2019). This contributes to belief in the trustworthiness of the stories and fosters empathy, commonly considered to be one of the key mechanisms in inter-group reconciliation (Oberpfalzerová et al., 2019).

\footnotetext{
8 The initiative My Story represents one of the key outcomes of the peacebuilding project Choosing Peace Together (CPT) run between 2010 and 2014 by Catholic Relief Services (CRS) and the Caritas of Bishops Conference of Bosnia and Herzegovina in Sarajevo, financed by USAID (Oberpfalzerová et al., 2019).
} 


\section{Key messages from the testimonies:}

- Focus on commonalities: Many listeners did not notice the storytellers' ethnic identity but focused instead on their suffering (Oberpfalzerová et al., 2019)

- Avoid blaming and stereotyping: Participants told their personal stories in a way that avoided blaming individuals of a particular ethnicity or bringing up narratives about who is culpable for the war and war crimes, contrasting with formal truth commissions that may engage in public shaming of perpetrators (Oberpfalzerová et al., 2019). Testimonies of forced mobilisation to war, 'moral exemplars', and the suffering of those from the other group, also contributed to reduction in blame and stereotypes (Oberpfalzerová et al., 2019).

- Recognition that all sides suffered and all sides committed crimes: Respondents with initially negative attitudes of the 'other' reported a decline in denial of the outgroup's suffering after hearing stories of suffering. This can counter competitive victimhood and lead to acknowledgment that the in-group also committed crimes (Oberpfalzerová et al., 2019)

The study also finds that storytelling has the capacity to engage people in a long-term process of reflection and attitude change (Oberpfalzerová et al., 2019). It encouraged respondents to seek out alternative information about the outgroup and to seek out opportunities for inter-group contact. There is also the potential for a wider impact on the community as listeners spread the messages of the public testimonies to others (Oberpfalzerová et al., 2019).

Challenges: There are some concerns, as with other truth-telling initiatives, that such storytelling and listening can result in re-traumatisation. In addition, there is the risk of sabotage as some audience reacted to stories by saying that they were not true and engaging in verbal attacks (Oberpfalzerová et al., 2019).

\section{Moral exemplars}

'Moral exemplars' are 'heroic helpers who risked their lives to rescue members from other groups during the time of war' (Čehajić-Clancy \& Bilewicz, 2017, 292). This was in spite of the prevalent in-group behaviour of either passivity or active participation in ongoing crimes (Čehajić-Clancy \& Bilewicz, 2020). Publicising narratives of rescue from ethnic cleansing and genocide can serve as moral exemplars. They can be a useful mechanism to decollectivise guilt, to rehumanise the other, and to (re)create positive and functional inter-group relations after violent conflicts (Čehajić-Clancy \& Bilewicz, 2020; Moll 2020). The aim of these stories is also to demonstrate that the idea of 'good neighbourhood' continued to exist during the war, as a message of hope for the present and the future (Moll, 2020).

Academic research has increasingly explored acts of rescue in contexts of mass violence, however, research on inter-ethnic help and rescue during the 1992-1995 war in BiH remains underdeveloped (Moll, 2020). While there is some recent research on the effects of structured workshops with youth in $\mathrm{BiH}$ (see below), more systematic research is needed on the impact of rescuer stories on post-conflict societies generally, particularly in less structured frameworks, such as reading stories or watching movies about rescuers (Moll, 2020).

Youth of different ethnic backgrounds in $\mathrm{BiH}$ have taken part in workshops that combine intergroup contact with learning about narratives of out-group moral exemplars, reflecting on heroism 
and morality, and meeting with a living 'rescuer'9 (Čehajić-Clancy \& Bilewicz, 2020 and 2017). Recent studies of the intervention finds that they significantly influenced participants' willingness to forgive the out-group's misdeeds and participants' belief in reconciliation (Čehajić-Clancy \& Bilewicz, 2020 and 2017).

Examples of initiatives that have adopted a moral exemplar approach include the RDC, which followed their work on the Human Losses Project with 'Positive Stories', as a different strategy to investigate, document, and publicise facts about the violence. It produced volumes of information about those who risked their lives to save others during the war (Moll, 2020; Rowen, 2013). Rescuers have also been profiled in documentaries and film. The Sarajevo-based Post-Conflict Research Centre's (PCRC) 'Ordinary Heroes' project in BiH has produced multiple documentaries on the topic. The Independent Journalists' Association of Vojvodina and the Association of $\mathrm{BH}$ Journalists also produced five documentaries in 2014-2015 about rescuers from BiH and Serbia, part of their 'Living Together' project (Moll, 2020).

The proposed Bosnian TRC was also to document rescuer stories (Dragović-Soso, 2016). Although the TRC never materialized, the interest in these stories is noteworthy as it was a deliberate innovation of the Bosnian TRC, not part of other such bodies in the world, which would have formed an official account of the truth (Moll, 2020; Dragović-Soso, 2016).

Challenges: In order for moral exemplars to serve as an effective method of changing perceptions and fostering willingness to forgive, they should not be seen as outliers, but rather seen as relatively common behaviour in the out-group (Čehajić-Clancy \& Bilewicz, 2020). To date, however, stories of help and rescue during the war are still not well known or widespread in $\mathrm{BiH}$ and elsewhere in the Western Balkans, despite various civil society initiatives (Moll, 2020). This is due in large part to the limited interest public authorities have generally shown in supporting these initiatives or in developing activities themselves (Moll, 2020). In addition, the RDC during its collection of stories found that many people were still afraid to tell such stories, refusing to be interviewed or requesting to remain anonymous. This is indicative of their environments where helping the 'other' is not viewed in a positive way (Moll, 2020).

\section{Two-way communication: 'The third way'}

In order to increase the chances for movement toward reconciliation, the conditions need to be set not only for optimal contact but also for the gradual change to two-way communication (Nikolić-Ristanović, 2015). Accusatory discourse and one-way communication have the tendency to estrange people, produce new conflict and undermine reconciliation (Nikolić-Ristanović, 2015). In Serbia, for example, there are considered to be two mutually exclusive and extreme discourses in the form of nationalism and anti-nationalism (Rehrmann et al., 2020; NikolićRistanović, 2015). This has led civil society to develop to a middle course of approaching the past - through a 'Third Way' of communication, aimed at open dialogue and two-way communication (Rehrmann et al., 2020). It involves people from all sides hearing and acknowledging that there was suffering on all sides, without minimising any suffering, in a way

\footnotetext{
9 This was part of the 'Ordinary Heroes' project, whose educational component included sessions throughout the Western Balkans that have brought together over 1000 people from different ethnic backgrounds to discuss the stories (Čehajić-Clancy \& Bilewicz, 2020).
} 
that enables all sides to obtain respect for the harms they have experienced. This in turn can lead to mutual understanding (Nikolić-Ristanović, 2015).

On the basis of analysis of their own activities, participants in Third Way workshops noticed the difference between one-way and two-way communication (Nikolić-Ristanović, 2015).

Communication where one does not listen to the other's voice, or where one's own truth is experienced as the only one, can block discussion, understanding and relationship-building (Nikolić-Ristanović, 2015) ${ }^{10}$ Participants also noted that abstract discussion, such as counting our and their victims, estranges, while concrete sharing of personal experiences can humanise people and contribute to mutual understanding (Nikolić-Ristanović, 2015). Participants felt better when they are allowed to speak about all that hurts them without anyone preventing them from doing so (Nikolić-Ristanović, 2015).

In addition to allowing for multiple truths, the Third Way enables discussion and recognition of multiple roles. It seeks to deal with the past in a way that empowers the victim to exit the role of victim and to regain control on their lives (Nikolić-Ristanović, 2015). The Third Way is also interested in war victimisation in the larger sense, in order to improve the understanding of the position of ex-combatants and perpetrators as well as the mechanisms which lead to committing crimes (Nikolić-Ristanović, 2015).

Challenges in adopting the approach include that it is a long-term, iterative process that's needs to be constantly re-examined and refined (Nikolić-Ristanović, 2015). In addition, in order to be more broadly accepted within society, it requires explicit and long-term support by authorities for establishing contact and two-way communication between members of different groups. This support, however, is often missing in Western Balkan contexts (Nikolić-Ristanović, 2015).

For more forms of unofficial truth-telling, see $\underline{\text { Art }}$ and Memorialisation

\section{Art and culture}

The growing interest in arts in transitional justice reflects a broader trend in peacebuilding scholarship and practice where the arts are used as an instrument to promote dialogue, new ways of thinking, and processes of reconciliation (Fairey \& Kerr, 2020; Haider, 2016). Art initiatives span a wide spectrum of creative activity driven by a range of stakeholders community workers, NGOs, heritage institutions, arts organisations, artists, etc. - engaging in, but not limited to, public art installations, photography, film-making, theatre, dance, and creative writing (Kerr, 2020). Cultural interventions can create more accessible forms of transitional justice and modes of engagement. In particular, they can:

- Amplify the outputs of trials, providing outreach and rethinking 'justice': Visual evidence deployed in the courtroom in the form of film, photography, and drawings has been

\footnotetext{
${ }^{10}$ A female workshop participant raised an example of the different effects that a one-way and a two-way communication can have: This involved a discussion about war-time rapes on Serbian state television, whereby a Bosniak woman started immediately to accuse Serbian politics, emphasising the enormous number of Muslim women who were raped. The Serb women on the panel felt provoked and started to present evidence about crimes against Serbian women. Their lack of mutual understanding and aggressive communication created a tense situation that was ultimately diffused when the workshop participant showed interest in the suffering of all women victims without trying to accuse anyone (Nikolić-Ristanović, 2015).
} 
immensely powerful (Kerr, 2020). Courts and other transitional justice institutions and actors are using arts-based approaches to supplement and translate judicial findings into language accessible to a wider audience, for example through documentaries, art exhibitions and graphic novels (Kerr, 2020; Kurze, 2016). Theatre and art productions can also be transported to remote areas where communities may not necessarily engage with courts or media (Simić, 2016).

- Provide alternative ways of truth-telling: While criminal trials involve the process of calling to account, 'artistic truth' calls for reflecting, rethinking and sharing (Simić, 2016). Artistic initiatives can provide a safe space for victims to share experiences - and to receive recognition and validation of their suffering (Simić, 2016; de Greiff, 2014; cited in Haider, 2016). They can also evoke powerful reactions among audiences to the effects of human rights violations in ways that trial transcripts and truth commission reports may not (de Greiff, 2014; cited in Haider, 2016).

- Allow for multiple truths: Creative and arts-based approaches can open up new deliberative spaces, catering to the recognition of different individual experiences of violence and to different, sometimes marginalised, voices (Fairey \& Kerr, 2020; Simić, 2016). Art makes it possible for multiple memories and competing narratives to be documented and to coexist simultaneously, without elevating any one memory above others (Kerr, 2020; Simić \& Milošević, 2014). Some projects seek not only to converse with the past, but also to reimagine the future (Kerr, 2020).

Despite greater interest in the arts, evidence of the impact of the arts as a catalyst for change in post-conflict settings remains fragmented and limited (Fairey \& Kerr, 2020). It is challenging to produce a systematic accounting of the wide range of activities involved (Simić, 2013).

\section{Exhibitions and performance activism}

\section{Youth Initiative for Human Rights (YIHR) ${ }^{11}$}

The YIHR, which operates in Belgrade, Zagreb, Sarajevo, Pristina and Podgorica, has a mandate for dealing with the past, addressing its legacy, and learning its lessons to build a better future (David, 2019). As part of YIHR, youth activist leaders have travelled throughout the region (and beyond) to stage performative events and organise meetings, with the aim of bringing different communities together to begin a bottom-up dialogue that questions historical narratives (Kurze, 2016). While many of the youth did not learn much about the war from their parents, they have sought out knowledge from alternative, transnational sources (Kurze, 2016).

YIHR's performative acts entail the creation of 'strategic confrontation spaces' (Kurze, 2016). The YIHR in Kosovo, for example, engaged in performance-based activism to confront 'competitive victimhood' with an inclusive reconciliatory message that 'victims are victims' (Kurze, 2016). Youth activists built a large white brick wall in a central square in Prishtina in 2011, with the names of 1,819 missing ethnic Albanian and Serbian persons inscribed on the wall. They also

\footnotetext{
${ }^{11}$ YIHR is a regional network of non-governmental organisations founded in 2003 with programmes in Serbia, Croatia, Montenegro, Bosnia and Herzegovina and Kosovo.
} 
placed empty chairs in front, symbolising that families are still waiting for recognition of the fate of their loved ones (Kurze, 2016).

Impact: This commemorative piece of art, which transformed into an ad hoc monument, provoked various reactions. Some people specifically sought the names of their family members, which was, for many, an emotional experience once the names were found (Kurze, 2016). People were generally surprised and moved when they saw how many names there were, observing in silence (Kurze, 2016). Some members of the Kosovar victim community resented the inclusion of Serbian names on the wall, however, and crossed them out (Kurze, 2016). Eventually, the creators had to take the wall down due to the vandalism and the temporary nature of the built structure (Kurze, 2016; Di Lellio \& McCurn, 2013).

YIHR BiH also launched a campaign called Flowers for 'Sarajevo Roses', which is the name given to the marks mortar shells created in the pavement on impact, which can often resemble the shape of pressed flowers (Kurze, 2016). Activists visited landmarks and painted the oftenfaded crater holes with dark red weather-resistant outdoor paint (Kurze, 2016). The campaign had two key aims: preserving commemorative history sites and raising awareness about the disappearance of these spaces due to urban development (Kurze, 2016). Art, in this case, can help to sustain a collective memory about mass atrocities, reintegrating fading symbols that represent the legacy of war into the daily lives of individuals occupying this space (Kurze, 2016). Public reactions to the initiative were mostly positive, but there were also critics who preferred the Roses and the memories to be less visible (Kurze, 2016).

\section{Historical Museum of BiH}

Recent research explores the work of artists from throughout the region as part of an open call, Reconciliations (2018), to contribute to the Historical Museum's exhibition about the Siege of Sarajevo. The exhibits include Memoria Bosniaca, by Vladimir Miladinović, a Belgrade-based artist, in which he redrew in ink wash selected documents relating to the siege, to address the collective sense of guilt at what was done in his name (Kerr, 2020). The beauty of the drawings serve to engage people in a different way with the story of the siege (Kerr, 2020). Miladinović has also reproduced the wartime diary of the Bosnian Serb military leader, Ratko Mladić, which was entered as evidence at his trial at the ICTY (Kerr, 2020). This has the potential to foster new forms of engagement with the archives of the tribunal (Kerr, 2020). Another exhibit, Bedtime Stories, by Lana Čmajčanin and Adela Jušić, now part of the Museum's permanent collection, recreates the experience of the siege, when people were forced to live for extended periods in small basement storage spaces in apartment blocks. The installation includes recorded narratives by people who lived through the experience (Kerr, 2020).

Through these and other exhibits, the Museum has come to be seen as a site of deliberation and national dialogue about BiH's contested past (Fairey \& Kerr, 2020). Activities were small-scale and piecemeal at the start, with programming evolving through iterative project cycles over time (Fairey \& Kerr, 2020). Reconciliations brought new audiences to the Museum, and encouraged different forms of engagement (Fairey \& Kerr, 2020). The Museum commissioned and engaged a new set of artists for Reconciliations 2, which focused more on the ICTY, drawing from court records and photographs entered into evidence (Fairey \& Kerr, 2020). 
Wider impact: The Museum's exhibits have ultimately created a participatory creative practice that has the potential to have a larger societal impact. Artists, educators, justice officials, and those who attend the exhibit can play an active role in carving out other spaces for plural narratives and deliberation about the past, present and future. The exhibits have often been accompanied with a more sustained programme of public activities, for example a series of workshops with history teachers in BiH that accompanied Reconciliations (Fairey \& Kerr, 2020).

\section{Balkan Diskurs Youth Correspondent Programme (BDYCP)}

BDYCP, led by the PCRC is a youth mentoring programme in $\mathrm{BiH}$ that seeks to build the capacities and voices of young artists and activists to produce counter-narratives that challenge divisive public discourse (Fairey and Kerr, 2020). It tends to attracts youth who are already open to inter-ethnic cooperation (Fairey and Kerr, 2020). Youth correspondents are encouraged to find community stories relating to inter-ethnic cooperation and moral courage in addition to other topics of their choice (Fairey and Kerr, 2020).

Impact: The programme's success was, in part, demonstrated by the number of stories and other forms of creative outputs (e.g. photo exhibitions, digital media projects) that were generated by its active participants and the audiences they reached. The 11 active participants on the Balkan Diskurs platform in the 2017 cohort published 29 stories and photo-essays, which were viewed 61,699 times via PCRC and Balkan Diskurs online platforms and social media (Fairey and Kerr, 2020). Topics, such as local heroes, gender discrimination in the workplace, and the Bosnian music scene, shifted the narrative away from a focus past conflict and inter-ethnic relations towards a more future-oriented, rights-focused and positive perspective (Fairey and Kerr, 2020).

While not framed as a reconciliation initiative, a qualitative study that followed the experiences of the 2017 cohort group finds that the programme has strengthened participants' trust in other ethnic groups; their positive attitudes toward inter-ethnic collaboration and reconciliation; and resolve to become multipliers of peace from within their own peer groups and societies (Fairey and Kerr, 2020). Of the 17 participants who attended the training, 11 stayed actively involved in the project after the workshops (Fairey \& Kerr, 2020, 154).

Alongside the BDYCP, the PCRP runs a nation-wide competition - the Srđan Aleksić12 Youth Competition - that challenges Bosnian youth to uncover stories from their communities that relate to moral courage, rescuer behaviour and inter-ethnic cooperation. Winners and runners-up receive the opportunity to publish their stories on Balkan Diskurs. ${ }^{13}$ Similar to Reconciliations, BDYCP was established through an iterative process, developed over various cycles of workshops and adapted from different initiatives. Specifically, it evolved from PCRC's 'Ordinary Heroes' programme and the Srđan Aleksic Youth Competition (Fairey \& Kerr, 2020).

\footnotetext{
12 He was a young Bosnian Serb who defended his Bosniak friend in his native town of Trebinje and was killed in the process.

${ }^{13}$ The Competition is a component of PCRC's award-winning Ordinary Heroes Peacebuilding Programme. https://balkandiskurs.com/en/category/youth-voices/youth-voices-srdan-aleksic-youth-competition/
} 


\section{Pillar of Shame - BiH}

The Pillar of Shame, launched in 2010 by two NGOs (one based in Germany and the other in Sarajevo), aimed to erect a permanent monument in the shape of two UN letters, filled with 16,744 shoes symbolically representing 8,372 victims of genocide - a critique of the UN's failure in Srebrenica (Simić, 2013). It was never completed. Research, based on media, documentaries and interviews, finds that key limitations of the campaign were a lack of engagement with the Serb population in Republika Srpska and Serbia, and inadequate funding (Simić, 2013).

The first phase of this project was successfully achieved (Simić, 2013). This entailed installing a pile of shoes, representing missing lives, temporarily in the front of Bundaberg Gate in Berlin on 11 July, 2010, marking the 15th anniversary of the genocide. In less than 2 months, the two organisations mobilised thousands of Bosnians in $\mathrm{BiH}$ and among the diaspora. The cities in which the centres for collecting shoes were established were all in the Federation of $\mathrm{BiH}$, however, the entity with a predominantly Bosniak population (Simić, 2013).

This first phase had a wider effect in society. Apart from these established collection centres, many people decided to collect shoes and become involved in the campaign on their own initiative (Simić, 2013). The campaign also engaged with several primary schools that were based largely in remote areas of Sarajevo, raising awareness about genocide among kids - and including them in drawing pictures, writing messages, or donating a pair of shoes (Simić, 2013). Some adults donated shoes that had special meaning to them, for example, one man donated shoes that he had worn on the day he was forced into a concentration camp; and a woman from Sarajevo donated shoes from her child who was killed during the siege (Simić, 2013). The fact that many people donated shoes and had a chance to express their opinions and positions in relation to genocide was deemed as a measure of success in itself (Simić, 2013).

Challenges: Although the campaign sought to establish a transnational 'collective memory' and develop a culture of remembrance beyond national borders, it failed to cross ethnic boundaries (Simić, 2013). There was a mutual lack of interest from civil society actors from both sides of the ethnic divide in working together (Simić, 2013). There was also no public support from UN agencies. Within $\mathrm{BiH}$, a number of Bosniaks in Parliament gave support, however, no one from the RS political elite supported the campaign (Simić, 2013).

The campaign was also unable to complete the second and third phases (a travelling exhibition and a permanent monument in Potočari/Srebrenica) due to limited funding. Organisers were concerned that participants may feel betrayed that the goal was not achieved (Simić, 2013).

\section{Thinking of You - Kosovo}

The suffering of ethnic Albanian victims of sexual violence during the war in Kosovo has largely been sidelined in trials (Krasniqi et al., 2020). The recent adoption by Kosovo's parliament of a reparations law for wartime sexual and gender-based violence marks formal progress, however, actual redress has been limited. One of the key obstacles for women to claim the reparations is the stigma surrounding wartime sexual violence, which has silenced women survivors (Krasniqi et al., 2020). The Thinking of You art installation by artist Alketa Xhafa Mripa attempted to confront this stigma and the exclusion of stories of sexual violence from the nationalist discourse; to gain recognition of the issue and the space for such stories to be told (Krasniqi et al., 2020). 
The public art was performed by hanging approximately 5,000 skirts and dresses from washing lines in the main football stadium in Prishtina. Organisers travelled across Kosovo to collect skirts and dresses, which were donated by members of the public, as well as local elites, who also helped to hang the items of clothing. It was seen as a way to encourage discussion about sexual violence - by 'airing dirty laundry in public' (see Krasniqi et al., 2020).

The project was unusual in that it received political support. The then president of Kosovo, Atifete Jahjaga (the first nonpartisan candidate and the youngest female head of state in Southeast Europe) donated a dress, promoted the installation (and subsequent documentary), and provided support through the National Council on Survivors of Sexual Violence (Krasniqi et al., 2020). The installation is considered to be one of a number of public activities leading to a degree of recognition of wartime rape in Kosovo (Krasniqi et al., 2020). The project was subsequently featured in a documentary film Mendoj Për Ty|Thinking of You, garnering further exposure (Krasniqi et al., 2020).

Challenges: A common critique and challenge, however, of such projects that focus on sexual violence is the use of language of victimhood, prevalent in dominant and patriarchal discourses that can reproduce the subordination of women (Krasniqi et al., 2020).

\section{Theatre}

Theatre can play a powerful role in 'facing the past', confronting and challenging 'truths' in the public domain (Simić \& Milošević, 2014). Unlike the judicial system, the theatre does not seek resolution, nor declare a 'verdict'. Rather it provides a space for people with opposing views to meet and freely express and share their feelings and thoughts about the performance and about the past (Simić \& Milošević, 2014). In contrast to judicial contexts, where time is linear, theatre can look simultaneously to the past, the present and the future (Simić \& Milošević, 2014).

\section{Most Mira - A Day of an Unlucky Man}

Most Mira (Bridge of Peace), a small peacebuilding NGO based in Prijedor, engaged youth in creating the play, A Day of an Unlucky Man (2016). It used comedy as a safe method to address contentious issues and to enable youth to have their own experiences of the 'other', outside of the confines of hostility and fear (Milatovic-Ovadia, 2016). The facilitators sought to unite participants in the critical humorous observation of social roles (e.g. politician, boss, student, cleric) instead of nationality or gender, and around common issues (Milatovic-Ovadia, 2016). Drama improvisations criticised contemporary social reality. In order to get a piece of identification, for example, the Unlucky Man had to undergo a long procedure of endless bureaucracy bordering on absurdity. ${ }^{14}$ The context of the story strongly resonated with the audience (Milatovic-Ovadia, 2016). The initiative can contribute to a 'wider process', as parents laughed together, watching their children's performances (Milatovic-Ovadia, 2016).

Humour also played an important role during workshops in breaking the ice, addressing conflict, and creating unity. During a drama improvisation exercise, for example, humour was used to

\footnotetext{
14 Including signing documents in different alphabets starting with Cyrillic and Latin and ending up with Hieroglyphs and cuneiform. It reflected the alphabet dispute in Bosnian society where Cyrillic and Latin alphabets are closely linked with issues of ethnicity and nationalism.
} 
comment on the attitude and behaviour of a facilitator who blocked suggestions and ideas, rather than being open (Milatovic-Ovadia, 2016). The workshops also enabled the discussion of difficult subjects, such as whether to have the character of a soldier in the play. The soldier, who was ultimately given a side role, had a strong presence (Milatovic-Ovadia, 2016). Young people noted how important such dialogues are to them, particularly given that they have little opportunity to discuss the past with their parents and in society in general, where there is a common refusal to discuss past events (Milatovic-Ovadia, 2016).

Several participants faced opposition from family members for taking part in Most Mira activities either because they disagreed with the aims or felt it had no value. Nonetheless, these students continued to take part. There was a real sense of solidarity in the group (Milatovic-Ovadia, 2016). In the feedback sessions, when reflecting on what had the most profound impact on them during the whole process, students emphasised the creation of new friendships, the laughter and the freedom of expression (Milatovic-Ovadia, 2016).

\section{Dah Theatre - Serbia}

Dah theatre sees itself as a truth-seeking mechanism that can provide a space where people with different opinions can meet and explore their varying perspectives; and help victims to seek justice (Simić \& Milošević, 2014). Dah's three performances, which engage with questions of responsibility to the past and accountability for crimes - Crossing the Line, Story about Tea, and The Shivering of the Rose - draw extensively on historical facts and documentary material about the war (Simić \& Milošević, 2014). Research on the effects of these productions, based on interviews and observation, finds that they have contributed to processes of reconciliation.

Crossing The Line (2009) was prompted by Women in Black, a Serbian feminist activist organisation (Simić \& Milošević, 2014). In Serbia, the play functions as a direct confrontation with the audience of the atrocities committed in 'their/our' name (Simić \& Milošević, 2014). They include people who felt guilty and developed a feeling of responsibility; those in Serbia who did not support what was happening, but felt their voices were not heard (Simić \& Milošević, 2014).

The play presented authentic testimonies from women survivors about their experiences with war. There are many in Serbia who do not accept the historical facts of the wars of the 1990s, yet audience members were emotionally affected by the performance and the human stories told (Simić \& Milošević, 2014). People often felt compelled to share their own stories, which Dah facilitates by organising conversations with audiences after the play (Simić \& Milošević, 2014).

The performance can also serve as an important source of recognition to victims and survivors. When performed in $\mathrm{BiH}$, the pain and loss experienced by Bosnians and the crimes committed were publicly recognised. Since the play and the theatre troupe comes from Serbia, this can translate into a sense of empathy felt by certain Serbian people towards Bosnian victims of war (Simić \& Milošević, 2014). The theatre company was also invited to perform in Kosovo.

Despite the confrontational nature of the play, audiences in Serbia have not responded negatively, with no attempts at intimidation or sabotage. This may be due in part to the inclusion of narratives given by Serb women of their suffering (Simić \& Milošević, 2014). However, government reactions to the play have been negative and polarising (Simić \& Milošević, 2014). 
The Story of Tea (2006) also deals with confronting the truth. The performance takes place in the space between spectators, who face one another. One of the true stories portrayed is the abduction and murder of nineteen Muslim men of Yugoslav nationality in Serbia. The murderers were caught and put on trial, but Serbia never issued a statement of condolence (Simić \& Milošević, 2014). At the start, the audience is served nineteen cups of tea, symbolising the men killed. At the end, actors put candles in those cups before leaving the stage. The audience often remain in the theatre, illuminated only by the nineteen candles held by the audience. The theatre in this sense has created a space for memorialising and reflection (Simić \& Milošević, 2014).

The Shivering of the Rose (2014) presents authentic testimonies from Bosnian women, along with personal diaries and literature from Argentina and Chile. It underscores the necessity of knowing the truth about missing loved ones, keeping their memories alive, and the constant presence of 'absence' (Simić, 2016). This again serves to confront the issue of missing people in Serbia, which has yet to be tackled by the government (Simić, 2016). While not a substitute for government action, the production acknowledges the need of people to mourn and commemorate victims, which can be significant to processes of reconciliation (Simić, 2016).

\section{Music}

\section{Pavarotti Music Centre}

The Pavarotti Music Centre, planned by War Child, opened in Mostar in 1997, and has since served as a safe space for shared activities across conflict divides. The Centre offers a range of in-house learning opportunities for young people in various musical genres. Interviews with diverse people close to the Centre reveal that it has provided a key contact place - a safe space for like-minded individuals to gather across nationalist divides to create music together (Howell, 2018 and 2015). The Mostar Rock School, in particular has a large multi-ethnic enrolment and long waiting list among youth unconcerned about nationality (Howell, 2018).

The interactions, friendships and social networks fostered at the Centre have had a 'snowball effect', increasing the scale of impact on cultural life in Mostar and on countering divisions (Howell, 2015). Some groups began to generate new artistic projects together, building opportunities for others to become involved in urban culture. One group of friends, for example, went on to establish a much-loved bar and arts venue (the Alternative Institute) in the centre of town. This venue has sought to explore an alternative culture away from the rigid confines of politically-imposed cultural identities. Members of the Institute went on to found the Abrašević Youth Cultural Centre (Howell, 2015), which continues to engage in important work, breaking down and providing alternative narratives to divided life in Mostar. While it is challenging for such cultural and arts-based projects to effectively counter the pervasive political nationalist rhetoric, the presence of such alternative spaces and narratives enables individuals to imagine alternative lives (Howell, 2015). This, in turn, increases the potential for further activism and promotion of a more inclusive society to other segments of the population (Howell, 2015).

\section{Memorialisation}

Memorialisation refers to a range of processes and forms of collective remembrance. Memorials, museums, monuments and other places of memory represent important sites where the past can be confronted (Haider, 2016). Unlike other transitional mechanisms, such as trials and truth 
commissions, memorialisation can involve large numbers of people over long periods of time. Memory sites often have the dual aim of providing for education/learning and redress/reflection (Haider, 2016). Memorialisation can be instrumentalised, however. Political actors and institutions can influence how collective memories are expressed in the built environment by selecting what to commemorate or ignore, including which memorials to build or which heritage buildings to renovate (Bãdescu, 2019a and 2019b; Clark 2016).

\section{Memorials and commemorative events}

Memorials have been an integral part of post-war reconfiguration in much of the Western Balkans, but they have primarily been developed in a divisive way (Bădescu, 2019a; Baliqi, 2017). The rigid storytelling of memorials can prolong ethno-national conflict through symbolic violence (Bădescu, 2019a). In Kosovo, for example, memorials and commemoration events are marked by selective representation that excludes the memory and truth of the 'other' side (Baliqi, 2017). Similarly, in $\mathrm{BiH}$, memorials reflect the narrative of one group and serve as ethnic markers (Bădescu, 2019a; Zyberi \& Letnar Černič, 2015). Many memorials in Sarajevo specifically blame 'Serbian criminals' for killing the 'citizens of Sarajevo'. This ethnicisation of guilt conflates the nationalist platform of the warring Bosnian Serb leadership with the entire ethnic group, leading to a symbolic humiliation of Serbs in urban space (Bădescu, 2019a). While this can produce an accountability with regards to the past, it can also have the opposite outcome of creating feelings of exclusion that may lead to further animosities (Bădescu, 2019a).

There are few memorials that do not fit this one-sided pattern. One example is the memorial that commemorates children who died during the siege of Sarajevo, without antagonising a particular group (Bădescu, 2019a). It was recently announced that a memorial space (Bijela Soba) will be established also in memory of children killed in Sarajevo. It will further serve as a place where school children can learn about what happened to others their age during the siege. ${ }^{15}$

Alongside remembrance of children as a unifying memory approach, another alternative for dealing with the memory of war emphasises the concept of the positive hero (see 'moral exemplar' under Truth-telling) (Bădescu, 2019a). For example, a Sarajevo street was renamed Srđan Aleksic in 2007, to commemorate the young Bosnian Serb who defended his Bosniak friend in Trebinje and was killed in the process. On the street, a plaque reads 'Without people like Srđan Aleksic and his heroic deeds, one would lose hope in humanity, and without it our life would have no meaning.' (Moll, 2020; Bădescu, 2019a). This memorial focuses on heroism and bravery and counters nationalist narratives - demonstrating the potential to establish inclusive memory practices (Bădescu, 2019a). Other cities throughout the Western Balkans have also since similarly commemorated Srđan Aleksic (Bădescu, 2019a). ${ }^{16}$ These acts are revered in the region as a step toward reconciliation (see Bădescu, 2019a).

\footnotetext{
15 The memorial is to be co-financed by the Minister for Veterans' Affairs of Sarajevo Canton and the Association of Parents Killed during the Siege. Sabic, A. (2020). Sarajevo Agrees New Memorial for Child Casualties of Siege. 11 December. Sarajevo: BIRN. https://balkaninsight.com/2020/12/11/sarajevo-agrees-new-memorial-forchild-casualties-of-siege/

${ }^{16}$ Such as Novi Sad, Podgorica, Tuzla, Mostar, Bihac, Foca and, most recently, Belgrade. In his hometown of Trebinje a sports complex has been named after him, while the Leotar Swimming Club, of which Srdjan was a member, organises an annual memorial swim.
} 


\section{Srebrenica-Potočari Memorial and Cemetery for the Victims of the 1995 Genocide}

Memorial sites such as Srebrenica-Potočari which honour victims from more than one ethnic group ${ }^{17}$ are rare exceptions (Zyberi \& Letnar Černič, 2015). Its central memory frame, however, is Serbian aggression against Bosnian Muslims (Jacobs, 2017). It is a pivotal site of collective memory and collective mourning (Jacobs, 2017).

Since only men are buried there, the memory that is conveyed through the monument and grave stones is one of male sacrifice for the Bosnian Muslim people (Jacobs, 2017). The installations in the Memory Room have as a focal point the atrocities committed against murdered fathers and sons and the subsequent suffering and losses of surviving mothers (Jacobs, 2017). It is this collective representation of maternal widowhood that has become the face of genocide in Srebrenica - and the focal point for remembrance (Jacobs, 2017).

Challenges: This representation of women has been criticised by some scholars as reflecting patriarchal norms in which women represent traditional maternal values of family and domesticity (Jacobs, 2017). There is an absence of memorialisation of the approximately 50,000 (mostly Bosniak) victims of mass rape (Jacobs, 2017). Some argue that an emphasis on rape through memorialisation may put victims and children born from rape at greater risk for further stigmatisation and marginalisation (see Jacobs, 2017). At the same time, however, the suppression of rape memory from public consciousness can contribute to the reproduction of silence and post-traumatic suffering of women (Jacobs, 2017).

Other community-based initiatives and local level practices of memory and commemoration have emerged to recognise individuals and groups who feel they have been left out of such processes (Simić, 2016). Collaboration between the Women in Black in Belgrade and the Centre for Women Victims of War in Zagreb may be a useful model for the establishment of memorial structures and commemorative events that bring together women from across the region to remember and honour the tragedy and trauma of rape in (Jacobs, 2016). Another approach could involve treating memorial spaces such as Srebrenica as built environments in which landscapes of memory include multiple discourses housed in one site to form a collective remembrance of shared suffering (Bosco, 2004; cited in Jacobs, 2016).

\section{White Armband Day - Prijedor, BiH}

Without a centralised institution such as the Srebrenica-Potočari Memorial Centre to coordinate memorialisation initiatives in Prijedor, alternative ways of memorialisation have taken place in the town. This has involved the development of a yearly commemorative event - White Armband Day on 31 May - to remember the campaign of ethnic cleansing. ${ }^{18}$ It has arisen through bottomup coordination between diaspora, returnees and local Bosnian Serb activists to advocate for a more inclusive memory narrative (Karabegović, 2019). ${ }^{19}$ It seeks to acknowledge what happened in Prijedor and acknowledge the losses of parents (Karabegović, 2019).

\footnotetext{
17 In this case Bosniaks and Bosnian Croats.

18 Having taken over the municipal government by force, Bosnian Serb authorities issued a decree on 31 May 1992 ordering all non-Serb citizens to mark their houses with white flags or bedsheets and to wear white armbands when leaving the house.

${ }_{19}$ On 23 May, 2012, twenty years following the initial decree about white armbands, the local government denied activist Emir Hodžić a permit to organise an art installation commemorating female victims from Prijedor. Out of
} 
White Armband Day garners a growing number of supporters each year in Prijedor and worldwide. In 2013, Bosnian Serb activists directly addressed the town's political leadership, asking for acknowledgement of the war atrocities. In 2014, over a thousand individuals joined the protests to lay out roses to remember child victims and as an invitation for community dialogue (Karabegović, 2019). Each year now, names of the children are read aloud in the main square, alongside a silent walk through the city centre, with each individual wearing a White Armband. This mobile memorial challenges existing memory narratives, in particular by focusing on the loss of 102 children in the community, ultimate victims of the war (Karabegović, 2019). This has since led to consultations between parents and the local government to create a monument to the children (Karabegović, 2019), with an agreement finally reached in $2020 .^{20}$

The participation of local Bosnian Serb youth is one of the key reasons why the White Armband Day and related initiatives continue to be successful (Karabegović, 2019). Diaspora members are also active members, returning for the commemorative events and changing their Facebook profile pictures to one with a white armband on 31 May in solidarity (Karabegović, 2019).

\section{Museums}

In recent decades war museums have re-examined how they present conflict, moving beyond simply displaying objects to using artefacts as narrative tools (see Niksic, 2020). Museums connect history (official and formal versions of the past) and memory (individual or collective accounts of personal experiences) (Kavanagh, 1996; cited in (Niksic, 2020). Museums can serve as outliers in the divisive memorialisation landscape prevalent in the Western Balkans. The

Sarajevo under Siege exhibition at the Historical Museum of $\mathrm{BiH}$, for example, seeks to tell the story of the war while avoiding the possibility of humiliation of a particular group (Bădescu, 2019a). The exhibit does not describe the siege of Sarajevo using an ethnic framework, but emphasises instead how all residents were besieged, focusing on their commonality of experiences, alongside their non-ethnicised attacker. The exhibit presents the siege of Sarajevo as a story of resilience, rather than of group victimhood (Bădescu, 2019a).

The War Childhood Museum (WCM) ${ }^{21}$ in Sarajevo is another example of an exhibit that does not narrate the 1992-1995 war in an ethnic way. Rather, it is narrated from the unique perspective of those who experienced the war as children (Niksic, 2020). The WCM organised its first exhibition in 2016 at the Historical Museum of $\mathrm{BiH}$ and opened in its permanent space in Sarajevo in 2017. The exhibit juxtaposes innocent childhood objects (toys, diaries, sweets etc.), that visitors may have also owned (or own) as children, and distressful testimonies, such as the loss of a family member. This can facilitate a deeper understanding of armed conflict and its ramifications (Niksic, 2020). The children, whose names are given along with glimpses of their personalities, are seen as real individuals rather than statistics, who are related to someone who still exists (Niksic, 2020). The children's testimonies are also devoid of identifying the perpetrator, of assigning blame or responsibility to any army, country, group or warring side, thus adopting an

protest, he stood in the main town square wearing a white armband. Pictures of him doing so spread across diaspora social networks and his act eventually grew into wider protests, involving a commemorative walk to remember 102 children who died in Prijedor during the war (Karabegović, 2019).

20 Bosnia's Prijedor mourns wartime children's deaths despite COVID-19. Sarajevo: BIRN, 1 June.

https://balkaninsight.com/2020/06/01/bosnias-prijedor-mourns-wartime-child-deaths-despite-covid-19/

21 The museum is the result of the book, War Childhood (2013) by Jasminko Halilovic, which requested personal reflections on the question: "What was a war childhood for you?" (in 160 characters) 
apolitical stance to the war (Niksic, 2020). The museum also includes a small section of oral testimonies of children from war-affected Syria (Niksic, 2020).

Impact: Recent qualitative research on the affective strategies employed at the WCM finds that the focus on personal stories enables visitors to experience war from the child victim's perspective; and to engage with alternative narratives, without the influence of ethno-national politics (Niksic, 2020). In addition, the apolitical stance of the testimonies prevents an affective experience of hostility towards another nation, leaving it up to the visitor to decide whether to assign blame (Niksic, 2020). Death at the WCM emphasises the innocence of the victims, honouring them, while giving little importance and not directly assigning blame to perpetrators (Niksic, 2020). Visitors enter into an affective practice of loss, but are given the space to construct their own narratives and to frame an alternative history, which may allow them to better cope with the realities of armed conflict (Niksic, 2020).

\section{Cultural heritage and the built environment}

Cultural heritage is intimately connected to notions of identity and belonging. Heritage sites are thus often deliberately targeted for destruction as part of an overall assault on a community's culture and history (Hisari \& Fouseki, 2020). There is limited research, however, on the role of urban heritage as tool for (or against) reconciliation (Hisari \& Fouseki, 2020). Ethno-nationalists in $\mathrm{BiH}$, for example, often view cultural heritage sites and institutions as tools through which to reinforce dominant political narratives about identity (Dougherty, 2019). Heritage preservation (e.g. the rebuilding of churches and mosques) and new monuments are often initiated that shape the public space along ethnic lines, obscuring any notion of a shared heritage (Wollentz, 2019).

In Serbia, there are a number of emblematic buildings in Belgrade that remain in ruins after the 1999 NATO bombings (Bãdescu, 2019b). The ruined Generalštab (former General Staff of the Yugoslav Army and the Ministry of Defense of Yugoslavia), for example, is the subject of much debate, with suggestions for the memorialisation of the ruins on the one hand, and a lucrative new construction on the other (Bãdescu, 2019b). Its fate may be determined by capital and allegiances rather than memory (Bãdescu, 2019b).

Shared spaces such as Vraca Memorial Park in Sarajevo and the Partisan Memorial Cemetery in Mostar (both dedicated to those who died in World War II), were popular parks prior to the 19921995 war. The victims remembered in these spaces are identified with the struggle against fascism (Dougherty, 2019). These spaces can help to forge a collective identity and foster a sense of belonging to a heterogeneous community, however, they have been abandoned, essentially deleted from collective narratives (Dougherty, 2019).

Restoring lost physical landscapes and particular built structures can help to bring communities together (Clark, 2016; Dougherty, 2019). There have been efforts by the Commission to Preserve National Monuments and other cultural heritage institutions and by concerned individuals and civil society groups to acknowledge the collective narratives evident in heritage spaces (Clark, 2016; Dougherty, 2019). In Mostar, for example, where heritage is also 'ethnicised' and little attention given to shared heritage, a group of youth in Rudnik transformed an electric substation into a monument dedicated to miners from the socialist period (Wollentz, 2019). The substation was overpainted resembling a shelf popular in Yugoslav households during the 1970/80s, drawn from personal stories. People of all ages and ethnicities joined in the process. It was a monument created by and for the community (Wollentz, 2019). 
Impact: Research, based on participatory observation and interviews, finds that the focus on miners and the participation of diverse community members allowed for the prominence of identities other than ethnic ones (Wollentz, 2019). Attention to the narrative of the worker also has the potential to unmake ethnic narratives. The monument illustrates how nostalgia can be a form of resistance to ethnic divisions - a way of envisioning a different future (Wollentz, 2019).

\section{Dialogue}

Dialogue in post-conflict contexts often involves discussing the past together in a way that challenges the way people think and communicate with one another (Bell, 2019). It can lay the foundation for inter-group reconciliation by bringing groups together to share their sufferings and experiences, to work on acceptance of each other without feelings of hatred, to get to know the 'other' and alter perceptions, and to work on a common, interdependent future (Bell, 2019; Radosavljević, 2018). A key benefit of being in contact and engaging in dialogue is that it helps to rehumanise the 'other', which, in turn, can foster empathy toward the other (see Bell, 2019, Haider, 2011). Given the varying definitions of dialogue, the ways in which dialogue is used in peacebuilding processes may differ (Šerá Komlossyová, 2019).

Challenges: Initiatives involving face-to-face and dialogue encounters often bring participants together based on ascribed roles - in the case of the Western Balkans, based on ethno-religious identities (David, 2018). Facilitators are also recruited along ethnic lines (David, 2018). There is a risk that such initiatives lessen the importance of other possible identities (e.g. gender, class, rural/urban location, profession, age etc). By elevating ethno-religious identity, the interpretation of historical narratives that evolve during the process of dialogue are seen through the prism of this structured division, rather than allowing for inter-sectional identities (David, 2018).

\section{Local governance mechanisms}

Local governance mechanisms have been established in Serbia (local councils), Macedonia (commissions), and Kosovo (committees) (Djordjević, 2018). They can serve as a channel for smaller communities to express their needs and interests, and as a forum for inter-ethnic dialogue in a municipality (Djordjević, 2018). Research finds that they have not been effective in bridging divides, however, as the concept of dialogue in these cases is perceived as either through the prism of solving inter-ethnic conflicts or of presenting and promoting different cultures and traditions (Djordjević, 2018). This can undermine the capacity of such mechanisms to be a forum for dialogue on issues that affect majority and minorities as members of a wider local community, and thus to strengthen social cohesion at the local level (Djordjević, 2018).

\section{Nansen Dialogue}

Throughout the Western Balkans, face-to-face encounter projects have become a frequent initiative among peacebuilding and reconciliation NGOs (David, 2019). The Nansen Dialogue was among the first entity to start face-to-face initiatives. ${ }^{22}$ There are currently 10 Nansen

\footnotetext{
22 'Nansen dialogue', originated in Norway, is a specific dialogue approach, based on three concepts: movement, visibility, and relations. Movement represents the physical movement of participants of dialogue workshops to 'neutral ground' and the mental movement away from stereotypical perceptions of the 'other'. Visibility refers to
} 
Dialogue Centres (NDCs) operating throughout the Western Balkans, employing more than 60 people (David, 2019). Dialogue activities have included seminars for local politicians and municipal administrators, parents, teachers, as well as joint activities for school children. Seminars aimed to build relationships between participants from different ethnic groups, and gave participants opportunities to ask questions of members of the other ethnic group in order to better understand their perspective and to share their own experiences and perspectives. Other seminars focused on skills and different models of multicultural education (Cleven, 2019).

Impact: A recent study, based on interviews (with staff, facilitators, participants and members of local action groups), finds that the NDC Sarajevo has created a viable model that contributes to de-ethnicising the everyday problems that local communities experience (Šerá Komlossyová, 2019). Workshops examined took place in cities, Zvornik and Jajce, and in rural towns, Srebrenica and Bratunac. The study finds that dialogue workshops contributed to the crucial formation of a new, common identity among participants and in many cases the discovery of shared concerns. In the case of Jajce, youth participants started to refer to themselves as the 'Nansen kids', forming an encompassing identity (Šerá Komlossyová, 2019). It is also in Jajce that students - direct and indirect beneficiaries of the Nansen dialogue processes - successfully initiated protests against the plans of the cantonal government to divide the multi-ethnic secondary education along ethnic lines, wanting instead to be educated together (Šerá Komlossyová, 2019). The government ultimately dropped their plans.

An important aspect in the design of NDC Sarajevo's dialogue initiative is combining inter-group dialogue with support for local activism. Dialogue, which involved discussion of contrasting viewpoints of war-related experiences, also aimed at the realisation of shared problems and similar perspectives on these problems. This in turn helped to break down stereotypes, build trust and fostered the will to cooperate to address shared problems (Šerá Komlossyová, 2019). Similarly, NDC Skopje facilitated dialogue seminars among Albanian and Macedonian communities that led to the identification of a shared concern for better education, regardless of ethnicity (Kelleher and Ryan, 2012).

Another study of the NDC Mostar dialogue project, connected to a segregated school in ProzorRama, $\mathrm{BiH}$, seeks to discover whether such initiatives have a wider community impact (Cleven, 2020). The study looks not only at the effect of dialogue on attitudes and prejudice, but also on social ties, social interaction and civic participation (Cleven, 2020). This was investigated through surveys of parents in Prozor-Rama and Capljina, a control town without a dialogue project.

Impact: The study finds similar positive trends in both towns towards higher levels of inter-ethnic trust and friendships and feelings of closeness to members of the other ethnic group (Cleven, 2020). These effects were occurring even in Capljina, with no dialogue initiative, primarily through everyday increases in contact with one another across the ethnic divide. This occurred even though the political arena and many public spaces remain segregated (Cleven, 2020).

While dialogue in Prozor-Rama did not seem to amplify the already positive effects occurring, it did have the effect of lowering in-group trust and dampening civic engagement relative to a control town (Cleven, 2020). This may be because ideas about one's own ethnic group may also be challenged through dialogue (Cleven, 2020). Since local associations are largely mono-ethnic,

making yourself visible to others and allowing others to become visible to you. Lastly, relationships can be strengthened through dialogue by fostering mutual respect and understanding (see Šerá Komlossyová, 2019). 
decline in in-group trust can undermine civic engagement; whereas any increase in out-group trust would not necessarily translate into increased civic engagement (Cleven, 2020).

\section{Youth Peace Camp (YPC) - Kosovo}

The YPC aims to gather young people from differing sides of the conflict, providing them a safe space for dialogue and engaging them in peacebuilding through human rights education activities (Radosavljević, 2018). It allows for the sharing of stories, to listen to and meet the 'other' side of the conflict, in many cases, for the very first time (Radosavljević, 2018).

Youth from throughout the Western Balkans (Serbia, Kosovo, Montenegro and $\mathrm{BiH}$ ) have taken part in the Camp. An evaluation of the YPC in Kosovo, based on surveys, questionnaires and observation, finds that there are positive correlations between the YPC impact and reconciliation (Radosavljević, 2018). Participants came from either the Serbian or Albanian community - from different regions or towns in Kosovo, where there are limited opportunities to develop relations with the 'other' (Radosavljević, 2018). Dialogue Day at the Youth Peace Camp 2018 was dedicated to sharing personal stories from the conflict. It involved four phases, beginning with sharing stories in mono-community groups, then combining communities - and ultimately bringing together participants who were on opposite sides of the conflict (Radosavljević, 2018).

Impact: The evaluation finds that the dialogue initiative contributed to positive changes in the perception of the 'other', primarily through 'working together with the other side on ideas that can facilitate reconciliation' (40 percent of respondents), through conversation about the conflict (30 percent), and through learning about the views of the other side (23 percent) (Radosavljević, 2018). The YPC aims to encourage sharing or personal experiences and stories, while avoiding political discussions. Sharing also has two interdependent roles: mutual understanding and acknowledgment of what happened during the war. These activities and processes contributed to open-mindedness and rehumanisation of the 'other' (Radosavljević, 2018). Participants frequently noted the development of empathy as an outcome of Dialogue Day - fostered through sharing, listening, acknowledgement and understanding (Radosavljević, 2018).

Wider impact: Although Camp activities are limited to 10 days, there is some evidence of continued wider impacts that endure past the duration of the Camp (Radosavljević, 2018). The last three days at the Camp were focused on creating follow-up activities to be implemented after the Camp's conclusion (Radosavljević, 2018). This contributed to awareness that participants could influence other members of their communities and contribute to the wider reconciliation process - and the motivation to do so (Radosavljević, 2018). Many of the respondents mentioned their work in changing the perception of others after returning to their communities, achieved in large part by sharing good experiences from the Camp, relaying the stories told, and introducing friends from the 'other side' to their own community (Radosavljević, 2018). Participants also sought to counter hate speech in their own communities. Most of the participants also participated in subsequent projects related to peacebuilding and reconciliation. For example, two of them opened NGOs dealing with reconciliation and capacity building and others worked on internationally supported peacebuilding projects (Radosavljević, 2018).

Challenges: Despite these wider effects, the main challenge with dialogue projects such as the YPC is their sustainability. If participants do not have the chance or the support to work on reconciliation and peacebuilding, the influence of the dialogue projects will likely stay solely with 
them or possibly only with their close community members (Radosavljević, 2018). Further, the persistence of divisive political structures is a strong limiting factor. As was noticed during the observation of the YPC 2018, the unresolved political situation between Kosovo and Serbia negatively influences communication between the two communities (Radosavljević, 2018).

\section{Education}

Reconciliation outcomes in the Western Balkans will rest in large part on the efforts of youth. It is thus essential to study the determinants of reconciliation in the younger generation (Meernik et al., 2016). A key influence in the lives of youth - education - has yet, however, to be systematically incorporated into transitional justice approaches (Karabegović, 2018).

Prior to the wars of the 1990s, schools in BiH brought together students of varying ethnicities and religious traditions (Osler \& Pandur, 2019; Meernik et al., 2016). In North Macedonia, prior to the conflict in 2001, students from both ethnicities studied in the same school shifts and sometimes the same classroom (see Bloodworth, 2020). Segregated schools and educational policies, created throughout the region during and since the wars, isolate students from one another, physically and through different curriculum and history textbook (Bešić \& Džuverović, 2020; Osler \& Pandur, 2019). In Serbia, only three classes are dedicated to the topic of the disintegration of the former Yugoslavia, and textbooks are required to cover the topic in less than 5000 words, effectively constraining critical history teaching (Geis et al., 2019). In North Macedonia, the 2001 Ohrid Framework Agreement provided groups with official status the right to attend school in their mother tongue (Bloodworth, 2020). This has had the effect of producing segregated education, with separate facilities and curriculum. Further, textbooks issued after the cessation of conflict discuss neither the armed conflict of 2001 nor pay adequate attention to the disintegration of Yugoslavia (Bloodworth, 2020; Todorov, 2016).

The way in which the 'truth' is curated in history education solidifies ethnic division, with onesided narratives that focus on victimisation of one's group and 'enemy images' of the 'other', rendering invisible any suffering of the other side (Bešić \& Džuverović, 2020; Oberpfalzerová et al. 2019; Osler \& Pandur, 2019; Meernik et al., 2016; Subotic, 2015). Students do not learn about shared experiences of the wars, which perpetuates views that one's group identity is entirely separate from that of others (Bloodworth, 2020; Todorov, 2016). This risks transplanting mistrust and past conflicts to today's young adults (Bešić \& Džuverović, 2020; Meernik et al., 2016).

\section{Mixed schools - contact}

Schooling provides a beneficial opportunity for young people to cultivate contact, dialogue and relationship building (Meernik et al., 2016). Research, based on a regional survey (BiH, Croatia, Kosovo, North Macedonia, Montenegro and Serbia) conducted by the ICTY Outreach Office of the opinions of high school and college students from 2011-2014, finds that those who are able to interact more frequently with students from other ethnic groups will be more likely to believe in the possibility of reconciliation (Meernk et al., 2016). Students from 'mixed' schools were 7.2 percent more likely to believe in the possibility of reconciliation (Meernik et al., 2016, 425). 


\section{The Mostar Gymnasium and the United World College (UWC) - BiH}

The Mostar Gymnasium is one of the first integrated schools in BiH. While still functioning under the 'two schools under one roof' principle with separate curricula and classes, internal borders have been deconstructed to some extent. Croat and Bosniak classrooms are alternated and there are shared spaces, including the library, computer lab, student council room and teachers' room (Forde, 2018; Hromadžić, 2011). The United World College (an international college) operates in the same place, with international and nationally mixed students (Forde, 2018).

Impact: Research finds that the Mostar Gymnasium has contributed to improved levels of interethnic interaction among youth, in a city with limited opportunities for such interaction (Forde, 2018). On a micro-level, some students sought out neutral spaces (the bathroom) to socialise with youth from the 'other side' (Hromadžić, 2011). It constituted a unique space that enabled experimentation with ethno-religious identity and re-negotiation of narratives (Hromadžić, 2011).

Challenges: In some cases, however, bringing students in proximity to each other, without school policies to engage students in meaningful cross-ethnic activities or interactions can fuel mistrust and fear among youth who continue to carry emotional wounds from the war (Hromadžić, 2011).

Another study, based on interviews with students attending the UWC, who had previously attended segregated schools, reveals that attendance at UWC has contributed to 'unlearning' the lessons of segregation and shaping new identities (Osler \& Pandur, 2019). One student commented about how they unlearn stereotypes through humour - joking about common problems and their shared experience of prior segregated education (Osler \& Pandur, 2019). Students were passionate about the need for an integrated school system to counter segregation that entrenches stereotypes of the 'other' (Osler \& Pandur, 2019).

Grassroots mobilisation to challenge existing structures of education and youth policy can contribute to creating shared spaces for youth in schools. The Association of Bosnians in France, for example, donated technological and computer equipment to a school in Mostar, with the condition that their donations were to be used for all students, regardless of the schools' otherwise parallel curricula (Karabegović, 2018). By providing enough computers for students to be together in the computer lab, their efforts triggered inter-group contact (Karabegović, 2018).

\section{Shared learning - North Macedonia}

In the absence of adequate political action for integrated education in North Macedonia, NGOs have adopted various initiatives (Loader et al., 2018). The Centre for Shared Education ${ }^{23}$, for example, working with UNICEF, has sought to develop a systematic approach to intercultural education in the country, drawing from Northern Ireland's experience of shared education and from existing intercultural education initiatives in North Macedonia (Loader et al., 2018). The latter included extracurricular multicultural workshops; and the Nansen model of integrated education, which encourages bilingual education (Loader et al., 2018).

Subsequently, USAID working with local partners implemented the state-wide 'Inter-ethnic Integration in Education Project (IIEP) (2011-2017), which sought to raise awareness of the

23 The Centre for Shared Education is leading an ESRC-funded project to develop a network of stakeholders to advance shared education in Bosnia and Herzegovina, Croatia and the Republic of Macedonia. 
importance of inter-ethnic education and foster capacity within the system to deliver it (Loader et al., 2018). Activities for students were delivered bilingually (and occasionally trilingually). The refurbishment of schools was used as an incentive to participate in integration activities (Loader et al., 2018). The programme included additional language-acquisition workshops, multicultural workshops, shared classes for English and sports, outdoor 'teaching in nature' classes, mixed extracurricular activities, such as art and performance, and excursions to local sites of interest, including those with cultural or religious importance for a particular ethnic group (Loader et al., 2018). The number of participants was limited to 24 students (12 Macedonians and 12 Albanians, gender balanced) in order to allow for meaningful encounters (Loader et al., 2018).

Impact and challenges: Interviews with staff of participating schools in North Macedonia found that while the programme contributed to positive encounters between different groups and learning about different cultures, it was less effective in addressing potentially contentious issues, such as discrimination and social injustice (Loader et al., 2018). This reflected a desire among staff to avoid disturbing the delicate harmony within the group (Loader et al., 2018).

\section{Extracurricular activities}

Research in North Macedonia points to the importance of multi-ethnic extra-curricular activities alongside integration within the schooling system (Kavaja, 2017). They have the potential to reduce foster contact that can result in the formation of cross-ethnic friendships (Kavaja, 2017). Sport is an activity that has been adopted throughout the Western Balkans and elsewhere as a means of uniting different conflict groups. While the competitiveness of sport and support for national teams can increase antagonism and sporadic fighting between ethnic groups on game nights, participation in sport can also facilitate social inclusion, cohesion and integration of divided ethnicities (Krasniqi and Krasniqi, 2019; Anastasovski et al., 2016).

The Open Fun Football Schools (OFFS), for example, is widespread in the Western Balkans. The aim of OFFS is for children to enjoy playing football together and to be able to meet and know children of different ethnicities, religions, ages, and physical capabilities - becoming part of the OFFS community of football. Sport is often combined with other social activities, such as eating together and listening to music. Leaders and coaches also belong to different ethnic groups. Parents are also involved with OFFS, often spending time with the other children and their families (Krasniqi and Krasniqi, 2019). The heavy reliance on local coaches and volunteers to undertake sport activities is considered a key success factor (Giulianotti et al., 2017).

Impact: Research on OFFS in Kosovo, including interviews with trainers and children, finds that the programme provides an opportunity for continuous interpersonal contact among volunteers, participants and parents - through training activities, mixed teams, and communication between trainers and parents (Krasniqi and Krasniqi, 2019; Giulianotti et al., 2017). This in turn contributes to breaking down social and psychological ethno-national barriers and to the development of friendly relationships (Krasniqi and Krasniqi, 2019; Giulianotti et al., 2017). Research finds that sport has been a unifying 'language' and that OFFS activities have led to a positive change in perceptions of the 'other' (Krasniqi and Krasniqi, 2019). A survey of school age children in North Macedonia also finds that young people learn values of tolerance and respect for difference through traditional games and sport; and that these activities foster openness to friendships with children of different ethnicity (Anastasovski et al., 2016). 
Art and theatre activities have also brought young people together. In Prijedor, for example, Most Mira (Bridge of Peace) seeks to counter the effects of segregated schools by providing a creative space for children from different ethnic groups to interact. Their art and education programmes focus not on the war, but on its consequences and current politics (Hrstić, 2020). Svitac, located in Brcko, $\mathrm{BiH}$, also runs arts and language workshops; and music, drama and other types of summer camps for all youth (Hrstić, 2020). By having children of different ethnicity enjoy simple things together like art or theatre, they grow up to see each child individually (Hrstić, 2020).

Challenges: If a child's foundational basis is built upon segregationist and nationalistic ideas and reaffirmed by the influence of their parents and respective communities, which can often be the case, the work of such youth initiatives can be undermined (Hrstić, 2020).

\section{History education and textbooks}

Rewriting history textbooks as a transitional justice method represents an attempt to acknowledge and deal with the past (Haider, 2013). Memory, historical consciousness and identity are reflected in and created by what is documented in textbooks and what is taught in history education (Haider, 2013; Todorov, 2016). The way in which history is taught can be a powerful tool for the exacerbation of or, alternatively, the prevention of conflict (Todorov, 2016).

\section{Multiperspectivity}

The presentation of a single narrative as 'the only accurate' truth in educational settings has limited value in divided societies with multiple versions of the 'truth' (Jeftić, \& Joksimović, 2014). In order for textbooks and curricula to contribute to transitional justice and reconciliation, they need to deconstruct historical myths; avoid ethnocentric approaches; and acknowledge the suffering each side has inflicted on the other and the experiences of each side (see Bloodworth, 2020; Todorov, 2016). 'Multiperspectivity' is an alternative method for teaching history that involves interpretation of the past from various perspectives and based on conflicting narratives. It also requires leaving space in between the conflicted narratives, such that students and teachers have a space for discussion and possible creation of a new narrative (Jeftić \& Joksimović, 2014).

Teachers play a big role in whether multiperspectivity can be effectively applied. If teachers bring their personal prejudices into the classroom, this affects students' perceptions and relations (Kavaja, 2017). Teachers also need to have the skills, capacity and willingness to build debate, discussion and consensus into the curriculum (Bloodworth, 2020). UWC offers teachers training in student-centred teaching methodologies (Osler \& Pandur, 2019). Research on the College finds that students appreciated environments where teachers foster open dialogue and young people can voice their thoughts without fear of criticism or censorship (Osler \& Pandur, 2019). School boards could also play an important role in developing a more unifying form of teaching (Kavaja, 2017). In North Macedonia, for example, their composition is usually mixed in schools where both Macedonians and Albanians attend. Yet, these boards have avoided dealing with issues of ethnicity and inter-ethnic relations (Kavaja, 2017).

\section{Moral exemplars}

The moral exemplars approach offers another possible alternative to the current method of history education (Čehajić-Clancy \& Bilewicz, 2020). Including such positive stories in curricula 
can influence perceptions and the way in which people engage toward one another (ČehajićClancy \& Bilewicz, 2020). In some educational programmes that incorporate such narratives, the aim is to develop more positive and caring attitudes of students toward others (Čehajić-Clancy \& Bilewicz, 2020). For further discussion, see 'Moral exemplars' under Truth-telling.

\section{Civic education}

In deeply divided societies, a key challenge is how to promote citizenship that integrates all groups and constructs a common identity (Baliqi, 2017). This can be facilitated through the promotion of a common civic education system that aims to provide students with skills for democratic participation in and beyond the classroom (Osler \& Pandur, 2019; Baliqi, 2017).

\section{UWC - BiH}

Recent research suggests that effective integrated schooling needs three elements: integrated classrooms; a reformed curriculum; and opportunities for students to work across ethnic divides for peace and reconciliation (Osler \& Pandur, 2019). The UWC model of service-learning and multicultural engagement has built up a reputation for effective engagement in cross-community projects designed to support processes of peace and reconciliation (Osler \& Pandur, 2019).

All UWC students are required to engage in service-learning, which gives students direct exposure to the aftermath of conflict and its ongoing impact, particularly on refugees and displaced persons. Research finds that students felt empowered to engage in peacebuilding through these experiences (Osler \& Pandur, 2019). In segregated schools, alternative opportunities for cross-community dialogue, such as mixed extracurricular activities and community service programmes should be created (Osler \& Pandur, 2019). The UWC, through its successful programming, is modelling integration to other institutions and presenting diversity as 'normal' (Osler \& Pandur, 2019). 


\section{References}

Anastasovski, I., Aleksovska, L., ZHivkovikj, V., Misovski, A., Nanev, L., \& Stojanoska Ivanova, T. (2016). Role of traditional games and sports in social and ethnical inclusion, integration and cohesion in the post-conflict and transitional societies among children of elementary schools. Research in Physical Education, Sport and Health.

https://repository.ukim.mk/bitstream/20.500.12188/9132/1/ROLE\%20OF\%20TRADITIONAL\%20 GAMES\%20AND\%20SPORTS\%20IN\%20SOCIAL\%20AND\%20ETHNICAL.pdf

Badescu, G. (2019a). Between Repair and Humiliation: Religious Buildings, Memorials, and Identity Politics in Post-war Sarajevo. Journal of Religion \& Society; Supplement Series, 19, 1937. http://kops.uni-konstanz.de/handle/123456789/51747

Bãdescu, G. (2019b). Making sense of ruins: architectural reconstruction and collective memory in Belgrade. Nationalities Papers, 47(2), 182-197. https://doi.org/10.1017/nps.2018.42

Baliqi, B. (2017). The Aftermath of War Experiences on Kosovo's Generation on the MoveCollective Memory and Ethnic Relations among Young Adults in Kosovo. Zeitgeschichte, 44, 619. https://papers.ssrn.com/sol3/papers.cfm?abstract_id=3048215

Bell, J. O. N. (2019). Reconciling after Transitional Justice: When Prosecutions are not enough, the Case of Bosnia and Herzegovina. Croatian International Relations Review, 25(84), 54-77. https://www.researchgate.net/publication/332441571_Reconciling_after_Transitional_Justice_W hen_Prosecutions_are_not_Enough_the_Case_of_Bosnia_and_Herzegovina

Bešić, M., \& Džuverović, N. (2020). How many truths are there? Reconciliation and agonistic dialogue in the former Yugoslavia. Southeast European and Black Sea Studies, 20(3), 455-472. https://doi.org/10.1080/14683857.2020.1793463

Bloodworth, A. (2020). Educational (de) segregation in North Macedonia: The intersection of policies, schools, and individuals. European Educational Research Journal, 1474904120907723. https://doi.org/10.1177/1474904120907723

Čehajić-Clancy, S., \& Bilewicz, M. (2020). Appealing to moral exemplars: Shared perception of morality as an essential ingredient of intergroup reconciliation. Social Issues and Policy Review, 14(1), 217-243. https://doi.org/10.1111/sipr.12067

Čehajić-Clancy, S., \& Bilewicz, M. (2017). Fostering reconciliation through historical moral exemplars in a postconflict society. Peace and Conflict: Journal of Peace Psychology, 23(3), 288. https://www.researchgate.net/publication/313817997_Fostering_Reconciliation_Through_Historic al_Moral_Exemplars_in_a_Postconflict_Society

Clark, J. N. (2016). Transitional justice as recognition: An analysis of the women's court in Sarajevo. International Journal of Transitional Justice, 10(1), 67-87.

https://doi.org/10.1093/ijtj/ijv027

Cleven, E. (2020). Making Connections? A Study of Interethnic Dialogue in a Divided Community in Bosnia and Herzegovina. Ethnopolitics, 19(2), 125-149.

https://doi.org/10.1080/17449057.2019.1647666 
David, L. (2019). Historical narratives as foundations for ethnicized identities:"facing the past" encounters in the Western Balkans and in Israel/Palestine. East European Politics, 35(4), 415432. https://doi.org/10.1080/21599165.2019.1616545

Di Lellio, A., \& McCurn, C. (2013). Engineering grassroots transitional justice in the Balkans: The case of Kosovo. East European Politics and Societies, 27(1), 129-148.

https://doi.org/10.1177/0888325412464550

Djordjević, L. (2018). Local bodies for interethnic relations in the Western Balkan states: Still an empty shell. Flensburg: European Centre for Minority Issues (ECMI).

https://www.ecmi.de/fileadmin/redakteure/publications/pdf/WP_106_Local_Bodies_for_Interethn ic_Relations_in_the_Western_Balkan_States.pdf

Dougherty, B. K. (2019). Letting Nature Swallow the Past: Politics, Memory, and Abandoned Monuments in Postwar Bosnia and Herzegovina. Nationalities Papers, 47(2), 248-263. http://search.proquest.com/openview/1d14aa9fdac3880452840aadcc81d039/1?pqorigsite $=$ gscholar $\& \mathrm{cbl}=36555$

Dragovic-Soso, J. (2016). History of a failure: Attempts to create a national truth and reconciliation commission in Bosnia and Herzegovina, 1997-2006. International Journal of Transitional Justice, 10(2), 292-310. https://doi.org/10.1093/ijtj/ijw005

Fairey, T., Kerr, R., Petrović, J. and Gow, J. (2020). New bearings in post-conflict evaluation: A principle based approach. London: King's College London.

https://kclpure.kcl.ac.uk/portal/files/140305103/New_Bearings_in_Evaluation_FINAL_PUBLISHE D_Dec20.pdf

Fairey, T., \& Kerr, R. (2020). What Works? Creative Approaches to Transitional Justice in Bosnia and Herzegovina. International Journal of Transitional Justice, 14(1), 142-164.

https://doi.org/10.1093/ijt/ijz031

Ferati-Sachsenmaier, F. (2019). Postwar Kosovo: Global and local dimensions of interethnic reconciliation processes. International Journal of Transitional Justice, 13(2), 310-327.

https://doi.org/10.1093/ijtj/ijz004

Fischer, M. (2013). Theoretical Approaches and Research Design. Dealing with the Past in the Western Balkans: Initiatives for Peacebuilding and Transitional Justice in Bosnia-Herzegovina, Serbia and Croatia. Berghof Report, (18), 19-28.

http://edoc.vifapol.de/opus/volltexte/2013/4678/pdf/BR18e_DwP.pdf

Forde, S. (2018). Movement as conflict transformation: Rescripting Mostar, Bosnia-Herzegovina. Springer. https://link.springer.com/content/pdf/10.1007/978-3-319-92660-5.pdf

Garson, M. (2020). Defying gravity: Evaluating the trickle-up effects of reconciliation programmes. Ethnopolitics, 19(2), 188-208. https://doi.org/10.1080/17449057.2019.1653017

Geis, A., Ristić, K., \& Petrović, V. (2019). "Screening" Transitional Justice in Serbia: ICTY Representations and the Memory of War Crimes in Serb Television Media. Deutsche Stiftung Friedensforschung.

https://www.academia.edu/41243990/_Screening_Transitional_Justice_in_Serbia_ICTY_Repres 
entations_and_the_Memory_of_War_Crimes_in_Serb_Television_Media_Forschung_DSF_45?e mail_work_card=view-paper

Giulianotti, R., Collison, H., Darnell, S., \& Howe, D. (2017). Contested states and the politics of sport: the case of Kosovo-division, development, and recognition. International journal of sport policy and politics, 9(1), 121-136. https://doi.org/10.1080/19406940.2016.1217251

Haider, H. (2016). Transitional justice: Topic guide. Birmingham, UK: GSDRC, University of Birmingham. https://gsdrc.org/topic-guides/transitional-justice/

Haider, H. (2013). Rewriting history textbooks. Encyclopedia of transitional justice, ed. Lavinia Stan, and Nadya Nedelsky, 93-97.

Haider, H. (2011). Social repair in divided societies: integrating a coexistence lens into transitional justice. Conflict, Security \& Development, 11(02), 175-203.

https://doi.org/10.1080/14678802.2011.572458

Hehir, A. (2019). Lessons Learned? The Kosovo Specialist Chambers' Lack of Local Legitimacy and Its Implications. Human Rights Review, 20(3), 267-287. LINK?

Hisari, L., \& Fouseki, K. (2020). Post-War Cultural Heritage Preservation in Kosovo: Rethinking the Implementation of Ahtisaari Plan Annex V. Heritage, 3(1), 98-115.

https://doi.org/10.3390/heritage3010006

Howell, G. (2018). Community music interventions in post-conflict contexts. The Oxford Handbook of Community Music. Oxford: OUP, 43-70.

Howell, G. (2015). Postwar Life-space and music in Bosnia-Herzegovina. Risk, protection, provision, and policy: Geographies of Children and Young People, 12.

https://link.springer.com/referenceworkentry/10.1007/978-981-4585-99-6_1-1

Hromadžić, A. (2011). Bathroom mixing: Youth negotiate democratization in postconflict Bosnia and Herzegovina. PoLAR: Political and Legal Anthropology Review, 34(2), 268-289.

https://doi.org/10.1111/j.1555-2934.2011.01166.x

Hrstić, E. (2020). Reconciling ethnic divisions in Bosnia and Herzegovina: The role of youth initiatives and diaspora in realizing the need for education reform. Western Balkans Youth Conference: Regional Cooperation and Integration, 50.

https://www.academia.edu/download/65176785/WBYC_2021_academiaEdu.pdf\#page=51

Jacobs, J. (2017). The memorial at Srebrenica: gender and the social meanings of collective memory in Bosnia-Herzegovina. Memory Studies, 10(4), 423-439.

https://doi.org/10.1177/1750698016650485

Jeftić, A., \& Joksimović, J. (2014). Divided Presentations in History Textbooks in Three Ex Yugoslav States: Discussing Implications for Identity Development. In Official Conference Proceedings: The European Conference on Psychology and Behavioral Sciences (pp. 47-60). http://papers.iafor.org/wp-content/uploads/papers/ecp2014/ECP2014_01326.pdf 
Karabegović, D. (2018). Aiming for transitional justice? Diaspora mobilisation for youth and education in Bosnia and Herzegovina. Journal of Ethnic and Migration Studies, 44(8), 13741389. https://doi.org/10.1080/1369183X.2017.1354165

Karić, T., \& Mihić, V. (2020). Construing reconciliation-lay people definitions in Bosnia and Herzegovina: A qualitative approach. Primenjena psihologija, 13(2), 211-242.

https://doi.org/10.19090/pp.2020.2.211-242

Kavaja, K. (2017). Ethnicity, politics, and education in Macedonia. European Journal of Education Studies, 3(9) https://oapub.org/edu/index.php/ejes/article/view/1036/2992

Kerr, R. (2020). Art, Aesthetics, Justice, and Reconciliation: What can art do? AJIL Unbound, 114, 123-127. https://doi.org/10.1017/aju.2020.24

Krasniqi, V., Sokolić, I., \& Kostovicova, D. (2020). Skirts as flags: Transitional justice, gender and everyday nationalism in Kosovo. Nations and nationalism, 26(2), 461.

https://www.ncbi.nlm.nih.gov/pmc/articles/PMC7357688/pdf/NANA-26-461.pdf

Krasniqi, S., \& Krasniqi, B. (2019). Sport and peacebuilding in post-conflict societies: the role of open fun football schools in Kosovo. Journal of Aggression, Conflict and Peace Research.

https://www.emerald.com/insight/content/doi/10.1108/JACPR-07-2018-0369/full/html

Kurze, A. (2017). Time for Change: Aid, NGOs, and Transitional Justice in Bosnia-

Herzegovina. Transitional Justice Review, 1(5), 2. https://ir.lib.uwo.ca/tjreview/vol1/iss5/2/

Kurze, A. (2016). \# WarCrimes\# PostConflictJustice\# Balkans: Youth, performance activism and the politics of memory. International Journal of Transitional Justice, 10(3), 451-470.

https://doi.org/10.1093/ijtj/ijw014

Kurze, A., \& Vukusic, I. (2013). Afraid to cry wolf: Human rights activists' struggle of transnational accountability efforts in the Balkans. In Transitional Justice and Civil Society in the Balkans (pp. 201-215). Springer, New York, NY.

Loader, R., Hughes, J., Petroska-Beshka, V., \& Tomovska Misoska, A. (2018). Developing social cohesion through schools in Northern Ireland and the former Yugoslav Republic of Macedonia: A study of policy transfer. https://archive.nyu.edu/handle/2451/42482

Mastrorocco, R. (2020). OSCE and Civil Society in the Western Balkans: The Road to Reconciliation. In Transformation and Development (pp. 83-100). Springer, Cham.

https://library.oapen.org/bitstream/handle/20.500.12657/37710/2020_Book_TransformationAndD evelopment.pdf? sequence=1\#page $=85$

Meernik, J., Golcevski, N., McKay, M., Feinberg, A., King, K., \& Krastev, R. (2016). Truth, justice, and education: towards reconciliation in the former Yugoslavia. Southeast European and Black Sea Studies, 16(3), 413-431. https://doi.org/10.1080/14683857.2016.1193975

Milatovic-Ovadia, M. (2016). Theatre and reconciliation: The Day of an Unlucky Man. Journal of Arts \& Communities, 8(1-2), 121-134.

https://www.academia.edu/download/56466735/_02_Theatre_and_reconciliation_The_Day_of_a n_Unlucky_Man._copy.pdf 
Moll, N. (2020). Promoting 'Positive Stories' of Help and Rescue from the 1992-1995 War in Bosnia and Herzegovina. An Alternative to the Dichotomy of Guilt and Victimhood?. Südosteuropa, 67(4), 447-475. https://www.degruyter.com/view/journals/soeu/67/4/article-p447.xml

Nikolić-Ristanović, V. (2015). Communication about the past and reconciliation: Lessons from the Western Balkan. Restorative Justice, 3(2), 188-211.

https://doi.org/10.1080/20504721.2015.1069090

Niksic, L. (2020). Affect of War: Content analysis of the War Childhood Museum in Sarajevo. Studying Museums in Qatar and Beyond, 100-129.

https://www.academia.edu/43838138/Affect_of_War_Content_Analysis_of_the_War_Childhood_ Museum_in_Sarajevo

Oberpfalzerová, H., Ullrich, J., \& Jeřábek, H. (2019). Unofficial Storytelling as Middle Ground Between Transitional Truth-Telling and Forgetting: A New Approach to Dealing With the Past in Postwar Bosnia and Herzegovina. International Journal of Conflict and Violence, 13, 1-20. https://doi.org/10.5167/uzh-173130

O'Reilly, M. (2016). Peace and justice through a feminist lens: Gender justice and the women's court for the former Yugoslavia. Journal of Intervention and Statebuilding, 10(3), 419-445. https://doi.org/10.1080/17502977.2016.1199482

Osler, A., \& Pandur, I. H. (2019). The right to intercultural education: students' perspectives on schooling and opportunities for reconciliation through multicultural engagement in Bosnia and Herzegovina. Intercultural Education, 30(6), 658-679.

https://doi.org/10.1080/14675986.2019.1626576

Radosavljević, N. (2018). The influence of dialogue projects on the reconciliation process in Kosovo: Give peace a chance? The case of the youth peace camp. ECMI Working Paper \#110. https://www.ecmi.de/fileadmin/redakteure/publications/pdf/Working_Paper__110.pdf

Rehrmann, C., Biermann, R. \& Tolliday, P. (2020). Introduction. In Societies in Transition: The Caucasus and the Balkans between conflict and reconciliation. Göttingen: Vandenhoeck \& Ruprecht GmbH \& Co. KG, T. https://www.ir.uni-

jena.de/polibamedia/dokumente/papers_+speeches_++reports/einleitung_societies+in+transition _rehrmann_biermann_tolliday_ripar.pdf

Rowen, J. (2013). Truth in the Shadow of Justice. In Transitional Justice and Civil Society in the Balkans (pp. 123-140). Springer, New York, NY.

Schwandner-Sievers, S., \& Klinkner, M. (2019). Longing for Lost Normalcy: Social Memory, Transitional Justice, and the 'House Museum'to Missing Persons in Kosovo. Nationalities Papers, 47(2), 232-247. https://www.cambridge.org/core/journals/nationalities-

papers/article/abs/longing-for-lost-normalcy-social-memory-transitional-justice-and-the-housemuseum-to-missing-persons-in-kosovo/B08166117CAD91D2DCF93E08AC861D8C

Šerá Komlossyová, E. (2019). Moving beyond personal change: Using dialogue in ethnically divided communities in Bosnia and Herzegovina. Conflict Resolution Quarterly, 37(1), 33-47. https://doi.org/10.1002/crq.21239 
Simić, O. (2016). 'They Say That Justice Takes Time': Taking Stock of Truth Seeking in Peru, Argentina and Serbia. Australian Feminist Law Journal, 42(1), 137-161.

https://doi.org/10.1080/13200968.2016.1185813

Simić, O., \& Milošević, D. (2014). Enacting justice: The role of Dah theatre company in transitional justice processes in Serbia and beyond. In The Arts of Transitional Justice (pp. 99112). Springer, New York, NY. https://link.springer.com/chapter/10.1007/978-1-4614-8385-4_6

Simić, O. (2013). 'Pillar of Shame': Civil Society, UN Accountability and Genocide in Srebrenica. In Transitional justice and civil society in the Balkans (pp. 181-199). Springer, New York, NY.

Sokolić, I. (2020). Reconciliation rising: the roles of the everyday and the informal in successful post-conflict reconciliation. Ethnopolitics, 19(2), 162-167.

https://doi.org/10.1080/17449057.2019.1653015

Strupinskienè, L. (2020). International Criminal Tribunal for former Yugoslavia (ICTY) and grassroots mobilization for justice: Insights from Bosnia and Herzegovina. Peace and Conflict: Journal of Peace Psychology. https://doi.org/10.1037/pac0000476

Subotic, J. (2015). Truth, justice, and reconciliation on the ground: normative divergence in the Western Balkans. Journal of International Relations and Development, 18(3), 361-382. https://link.springer.com/article/10.1057/jird.2015.13

Todorov, P. (2016). Teaching History in Macedonia after 2001: Representations of Armed Conflict between Ethnic Macedonians and Ethnic Albanians. Eckert. Die Schriftenreihe Studien des Georg-Eckert-Instituts zur internationalen Bildungsmedienforschung, 111. https://www.vrelibrary.de/doi/pdf/10.14220/9783737006088?download=true\#page=111

Touquet, H., \& Vermeersch, P. (2016). Changing frames of reconciliation: The politics of peacebuilding in the former Yugoslavia. East European Politics and Societies, 30(1), 55-73.

https://doi.org/10.1177/0888325415584048

Wollentz, G., Barišić, M. \& Sammar, N. (2019) Youth activism and dignity in post-war Mostarenvisioning a shared future through heritage, Space and Polity, 23:2, 197-215.

https://doi.org/10.1080/13562576.2019.1635443

Zyberi, G., \& Letnar Černič, J. (2015). Transitional Justice Processes and Reconciliation in the Former Yugoslavia: Challenges and Prospects. Nordic Journal of Human Rights, 33(2), 132-157. https://doi.org/10.1080/18918131.2015.1047615 


\section{Suggested citation}

Haider, H. (2021). Transitional justice and reconciliation in the Western Balkans: approaches, impact and challenges. K4D Helpdesk Report. Brighton, UK: Institute of Development Studies. DOI: 10.19088/K4D.2021.033

\section{About this report}

This report is based on twelve days of desk-based research. The K4D research helpdesk provides rapid syntheses of a selection of recent relevant literature and international expert thinking in response to specific questions relating to international development. For any enquiries, contact helpdesk@k4d.info.

K4D services are provided by a consortium of leading organisations working in international development, led by the Institute of Development Studies (IDS), with Education Development Trust, Itad, University of Leeds Nuffield Centre for International Health and Development, Liverpool School of Tropical Medicine (LSTM), University of Birmingham International Development Department (IDD) and the University of Manchester Humanitarian and Conflict Response Institute (HCRI).

This report was prepared for the UK Government's Foreign, Commonwealth and Development Office ( $F C D O)$ and its partners in support of pro-poor programmes. Except where otherwise stated, it is licensed for non-commercial purposes under the terms of the Open Government Licence v3.0. K4D cannot be held responsible for errors, omissions or any consequences arising from the use of information contained in this report. Any views and opinions expressed do not necessarily reflect those of FCDO, K4D or any other contributing organisation.

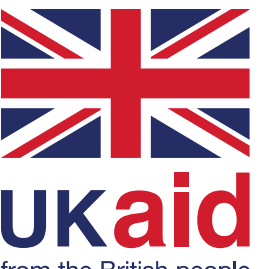

(c) Crown copyright 2021. 